\title{
"Comparative Constitutional Law and Legal Culture: Asia and the Americas": an overview of the CRN01 under the Law and Society Toronto, 2018 Meeting
}

\author{
Fernanda Duarte ${ }^{1}$ \\ Rafael Mario Iorio Filho ${ }^{2}$ \\ Ronaldo Lucas da Silva ${ }^{3}$
}

The Collaborative Research Network (CRN) is a Law and Society Association's iniciative that seeks to develop cross-disciplinary and cross-national research projects which intend to overcome the disciplinary barriers enabling the growth and integration of the social study of law. Organizing theme sessions for the LSA annual meetings, the CRNs can be a forum in which scholars, professors, students, as well as practitioners who are interested in interdisciplinary studies can organize discussions, share work, exchange ideas and build networks.

The CRN 01 - named Comparative Constitutional Law and Legal Culture: Asia and the Americas - was created in 2015, during the LSA Seattle meeting. It examines legal development, constitutional law and legal cultures from the perspectives of both legal sociology and comparative law regarding Asia and the Americas. In this age of globalization, when economic ties between these regions are gaining strength and momentum, it becomes a necessity to study them comparatively. This is especially important when developing economic relationships bring issues such as the rule of law and protection of human rights to the fore. In particular, it seeks to understand how political and historical paths, as well as global influences such as universalization of human rights and democratic constitutional values, have shaped the formation and evolution of constitutional law and legal culture in these regions various countries. It further seeks to examine the manifestations of contemporary legal culture in the political aspects of constitutional law, and in implementing democratic processes and human rights. The $\mathrm{CRN}$ brings together scholars engaged in these thematic and regional foci.

The CRN 01 would like to acknowledge the support given the following LSA Law and Society Association, Estácio de Sá University (UNESA) and Institute of Comparative Studies in Conflict Institutional Management - INCT-InEAC/UFF.

In 2018 CRN 01 took part in the International Meeting on Law and Society, in Toronto, Canada which took place from June, from June $7^{\text {th }}$ to June $10^{\text {th }}$. This time

\footnotetext{
${ }^{1}$ Professor of Law, PhD. LSA/CRN01 organizer. PPGD/UNESA and UFF. Brazil.

${ }^{2}$ Professor of Law, PhD. LSA/CRNO1 organizer. PPGD/UNESA and UFF. Brazil

${ }^{3}$ Professor of Law. LSA/CRNO1 organizer.UNESA, Brazil
} 
theCRN 01 activities have shown an amazing growth. It has sponsored 23 paper sessions and one "author meets readers" sessionas following.

\section{Constitutional law and legal culture in comparative perspectives: Asia and the Americas}

In this age of globalization, when economic ties between Asia and the America are gaining strength and momentum, it becomes a necessity to study their legal cultures comparatively. This is especially importante when developing economic relationships bring issues such as the rule of law and protection of human rights to the fore. This sessison examines legal development, constitutional law and legal cultures from the perspectives of both legal anthropology/sociology and comparative law. In particular, this session seeks to understand how political and historical paths, as well as global influences such as the universalization of human rights and democratic constitutional values, have shaped the formation and evolution of constitutional law and legal culture in countries in Asia and the Americas.

\section{Session I}

Chair/ Discussant: Denis De Castro Halis - Faculty of Law / University of Macau

\section{Process in Brazil and the United States: more different than a first analysis indicates}

The present work intends to establish a brief comparison between the safe harbor institutes of the North American right and the spontaneous appearance of the Defendant to argue the invalidity of the summons in the Brazilian law. This debate arose in the wake of the discussions initiated by the NEDCPD research group and the participation of its members in the CRN-1 of the LSA meetings. The interdisciplinarity, which presents itself as the background of the researches developed by the group, led us to analyze the two institutes through a socioanthropological reference, understanding the manifestations of Law as products of local knowledge. For this we use as theoretical framework the works of Clifford Geertz and Pierre Bourdieu. We intend the comparison between the institutes will allow us to reinforce the statement our research group has been stating in recent years which is the understanding of due process of law in Brazil is different from than the American although the institute has an identical literal translation.

Presenter

Bruno Rezende - Universidade Estácio de Sá - UNESA /Brazil

Co-Author

Carolina Freitas Universidade Estácio de Sá - UNESA /Brazil 


\section{The Future Role of Comparative Law in Legal Education as Exemplified by the BRICS Countries}

The BRICS countries (Brazil, Russia, India, China and South Africa) have recently formed a new "dialogue and cooperation platform", which is challenged to make a contribution to the global governance debate. The BRICS cooperation is being challenged by arguments about their great diversity, which is also reflected in the great legal diversity of the entire world. Based on previous research (The BRICS-Lawyers' Guide to Global Cooperation, CUP 2017) there is no prior limit as to scope and the fields as well as legal instruments of BRICS cooperation and the BRICS have already initiated various initiatives. Against the backdrop of the world's as well as the BRICS' legal diversity, the present article aims to compare the status quo of legal education in India, China, Brazil and Ecuador so as to answer the question about the origins of the diversity of law. In particular, the paper seeks to answer whether the diversity - and the often related arguments about an incompatibility of laws from different jurisdictions - is rooted in the laws governing legal education, the curricula of law schools or in other, non-legal causes, such as culture, history or language. As law faces serious challenges from the complexity of regulatory affairs in a rapidly changing and increasingly interdisciplinary environment, the findings sought are expected to contribute to the debate about the future role of comparative law in particular and the design of legal education in general.

Presenter

Rostam J. NEUWIRTH - University of Macau, Faculty of Law

\section{The Authority of Law: meanings and obedience in Argentina}

The goal of this research, based on the interpretative tradition, is to understand the meanings of the authority of law in Argentina through a philosophical-cultural analysis of its conceptual conditions, and a theoretical-empirical research on the forms, beliefs and motivations behind (lack of) law compliance as a primary manifestation of the authority of law. It will be a qualitative study, based on grounded theory, that will also seek to contribute to the understanding of the rule of law, trust in law and legality in Latin America.

Presenter

Agustina Ramon Michel - Universidad de Palermo

\section{Revealing the Concept of Brazilian Legal Culture - An Anthropological Approach}

This work aims to understand how the category Legal Culture has been developed in Brazil. It is a research that is still under development, being debated in the research group NEDCPD, of the Graduate Program of the Estácio de Sá University, where we intend to map how the Brazilian legal field understands, conceptualizes and approaches the category Legal Culture and how it is related to the Law. In this sense, inspired by anthropological studies and the notion of the relationship between Law and Society, we understand that Law is embedded in a particular culture with local values. Thus we have a special dialogue with CRN1's concerns, as we seek to reflect on issues related to the Brazilian legal culture. Applying the Discourse Analysis's Semiolinguistic methodology and research methods borrowed from Cultural Anthropology, we seek to illuminate, catalog, organize historically what is said about this category, highlighting its 
meanings. Our work carries out a study also using by the method of comparison by difference with North American approaches, once this is category is not usually seen in debates in Brazil.

Presenter: Cristina Iorio - Universidade Estácio de Sá - UNESA /Brazil

PresentingCo-Author:

Ronaldo Lucas da Silva - Universidade Estácio de Sá - UNESA /Brazil

\section{Session II}

\section{Chair / Discussent}

Discussant: Asya Ostroukh-University of the West Indies

\section{The role of legal doctrine: a comparison by contrast between Brazilian and North American legal cultures}

The present work is the result of our researches concerning the understanding of the marks that characterize the Brazilian legal culture which are revealed through the method of comparison in contrast to the North American legal culture. Using the methodology of Semiolinguistic Discourse Analysis to showcast its three places of the production of the senses (doctrine, rhetoric and elements of justification) we aim to describe how Brazilian legal doctrinal discourse is organized, dynamized and legitimized. In particular, we pick the doctrines of the so-called disciplines Introduction to the Study of Law (IntroduçãoaoEstudo do Direito, in Portuguese) and Introduction to the U.S. Legal System, because they reveal an idealized didactic concern of how thought is or should be understood.

Presenter

Fernanda Duarte - UNESA e INCT/InEAC/PROPPI/UFF

PresentingCo-Author- Rafael Mario Iorio Filho - Universidade Estácio de Sá e INCTInEAC

\section{Human rights in the perspective of a transforming constitutionalism}

It is based on the work of the creator of the South African Constitution known as "transformational constitutionalism", comparable to an agent whose mission is to induce major social changes through the political process, without violence and on a legal basis. The object of this text that seeks into judgments of the Constitutional Court of South Africa, the influence of the ethical prism of Ubuntu in its decisions involving social rights, after apartheid ended. It seeks to define some policies of recognition responding to the contemporary challenge of democratizing democracy in the sense of a new understanding of recognition and redistribution policies, adhering the concepts proposed by Sousa Santos in relation to human rights and interculturality, democracy 
and constitutionalism. It starts on the assumption that, in this globalized and multicultural world, the experiences lived through the decisions of the South African Constitutional Court, towards a "transformational constitutionalism" founded by the basis of Ubuntu, can serve as a guiding reference to give practical effectiveness to the corpus of Human Rights, in an intercultural dialogue, essential to researchers and interpreters of Law, particularly those dealing with Human Rights and issues involving democratic action among peoples.

Presenter

Edna Raquel Hogemann- UNESA

\section{Grinding Down the Edges of the Free Expression Right in Hong Kong}

Out of the ashes of the "Occupy Central" street protests that gripped Hong Kong in 2014 emerged the 'localist' movement, which advocates for total autonomy or even independence from the rest of China. Though it remains a fringe political position in the Region, it touches upon one of the mainland's "bottom lines" and so pushback against the movement has been intense. The Basic Law, Hong Kong's quasi-constitution, protects the right to free expression - though, as in many jurisdictions that right is not absolute. This paper argues, however, that the local government has declined to pass a law that seeks to limit certain forms of political speech and have that law tested by the courts for consistency with Hong Kong's constitutional structure. Instead, it has resorted to a series of extra-legal manoeuvres, including warnings to secondary school teachers that they could be fired for discussing independence in the classroom, the denial of licences to members of localist parties wishing to set up stalls at a public festival, threats of expulsion to pro-localist university students, and more. Importantly, It has done this in entirely absent a robust public and legal discussion about such a limitation. In the long run, this grinding down of the expression right outside the review of the judiciary is deeply troubling and can be understood as part of a global shift to authoritarianism in erstwhile liberal, rights-based jurisdictions.

Presenter

Stuart Hargreaves - Faculty of Law, the Chinese University of Hong Kong

\section{The constitutionalization of international law through the jurisprudential analysis of the Inter-American Court Of Human Rights (IACHR)}

In this project,we consider the relevance of the Inter-American System for the Protection of Human Rights as a foundation for the exposition of interconstitutionalism, a theory defended by the Professor Gomes Canotilho.To achieve this goal, we will present the historical guidelines of the South American continent, specifically in the second half of the 20th century.Forilustrate the relevance of the entry to the Latin 
American countries as signatories of the American Convention on Human Rights (ACHR) and the transition to international constitutional cooperation will be present the Velásquez Rodrigues v. Honduras case, a pioneering action of the Inter-American Court of Human Rights (IACHR) in re-democratized countries.Secondly,we will proceed to an analysis of four Cases Law's of IACH to ilustrate a transition to a new concept of state sovereignty and the main points of debate about the maturation of constitutionalization of international law, in view of the obligation of the signatory states to respect the norms established by the ACHR and the feasibility of the supremacy of IACHR and the feasibility of the supremacy of IACHR understanding of national constitutional norms.In conclusion, this project shows the possible gaps in the Jurisprudence of IACHR has by examing their usage of Cases from the European Court of Human Rights as a guidance to improve the Constitution of the Latin America Countries and further enshrine the protection human's digninty in this Continent.

Presenter

Beatriz Mendes Niyama- Pontifícia Universidade Católica de Campinas (PucCampinas)

PresentingCo-Author

Gabriel Luís Massutti de Toledo Leme - DevryUniversity - METROCAMP - Brasil

\section{Was Justice Antonin Scalia a Perfect Example of Ronald Dworkin's Ideal Judge Hercules?}

Justice Antonin Scalia and legal philosopher Ronald Dworkin had a published debate over different meanings of originalism and how judges should interpret hard cases. In responding to Dworkin's critique of him, Scalia boldly declared, 'Professor Dworkin and I are in accord: we both follow "semantic intention".' (Scalia, A Matter of Interpretation, 144.) Though Dworkin would almost certainly not agree with this categorization, it is worth examining the degree to which their respective theories of judicial interpretation overlap. This will be accomplished through an examination of the characteristics of Dworkin's ideal judge (Hercules) as set out primarily in Law's Empire. This analysis will be placed in the context of Dworkin's response to what he sees as the flaws of legal positivism. I will then compare Hercules to the jurisprudence of Justice Scalia, drawing from both his theoretical writings and selected Supreme Court opinions. While not a complete overlap, this comparison will reveal more similarities than may at first be apparent. This in turn will shed light on the larger debate between originalism (often associated with Scalia) and living constitutionalism (which shares its roots with Dworkin's theories of interpretivism and law as integrity). Of interest here is the question of whether judges can reasonably be confined to the existing corpus of the law in deciding cases for which there is no clear legal precedent and what the implications of that approach would be. 
Presenter

Ryan Fortson - University of Alaska Anchorage

\section{Session III}

In this age of globalization, when economic ties between Asia and the America are gaining strength and momentum, it becomes a necessity to study their legal cultures comparatively. This is especially importante when developing economic relationships bring issues such as the rule of law and protection of human rights to the fore. This sessison examines legal development, constitutional law and legal cultures from the perspectives of both legal anthropology/sociology and comparative law. In particular, this session seeks to understand how political and historical paths, as well as global influences such as the universalization of human rights and democratic constitutional values, have shaped the formation and evolution of constitutional law and legal culture in countries in Asia and the Americas.

Chair:Young Jung - UW-Law School / Chonbuk National University(Law School)

Discussant:Lucia Frota Pestana de Aguiar Silva - Universidade Estácio de Sá

\section{The New Brazilian Judicial Precedent System: a Comparative Study Between Civil and Common Law Tradition Countries}

This paper intends to analyse to which extent Brazil's recent judicial precedent system has been influenced by the Common law tradition stare decisis doctrine. Firstly, it will outline the differences between the Common and Civil law systems, delineating their main characteristics and attributes, in particular the precedent building mechanisms available within each system. Secondly, it will look into the current Brazilian judicial system and its practices, analyzing its growing tendency to lean towards the use of the Common law binding precedent mechanism, in order to guarantee the consistency of rulings. The paper will demonstrate the challenges faced by this judicial system, recognizing that over 79 million cases are today under judicial appreciation in Brazil, a great percentage of which discussing the same issue. Thirdly, it will discuss how the new precedent system was developed along years by doctrine studies, and finally materialized in the 2015 Civil Procedure Code, highlighting its conception not only upon mechanisms pertaining to the Common law tradition, such as the binding precedents, but also making use of Civil law based procedures. Finally, it will demonstrate that today's Brazilian judicial precedent system must be interpreted as a product that merges Common law related mechanisms with Civil law logic, resulting in a new peculiar system, that better fits the country's reality. 
Presenter

Nilo Rafael Baptista de Mello - UNESA-RJ

\section{The neo-constitutionalism of Brazil: rethinking the appropriation of indeterminate concepts by the Courts}

Brazilian law has been receiving important influence from international theories, which discuss a supposed new constitutional paradigm, designated as "neo-constitutionalism". This new way of absorbing the constitutional theories, evidenced from the Constitution of 1988, involves important premises, which can be synthesized from the recognition of the normative force of legal principles and their overvaluation associated with a certain rejection of formalism, which reverberates in a new way of methodologically treating legal reasoning, coupled with the "techniques" of weighting and theories of argumentation that have been appropriated in a discretionary manner by the Brazilian legal field. The treatment accorded to fundamental principles and rights in Brazil has been given in an abstract way, without correspondence with the reality of judicial practices, which allows us to think about how our Courts have been dealing with activism and refraining their action, so as to eventually allow for some confusion and indissociability between the roles of the judge and the legislator, authorizing moral and ethical judgments to justify decisions that may be dissonant to the content of the law.

Presenter

Daniel Puerari - UNESA

Presenting Co-Author

Vanele César - UVA

Non-Presenting Co-Author

Bárbara Baptista - UVA

\section{BRICS Countries and Their Cooperation in the Field of Competition Law and Policy: A New Voice in International Antitrust?}

In the field of competition law the international legal regime is virtually non-existent. Despite certain success of regional integrationist developments that led to a significant degree of harmonization and convergence of the substantive competition rules, their enforcement remains primarily national. On that background the economic integration of the BRICS countries can provide a much needed impetus for the global integration of the competition enforcement. Despite economic, political, and social differences among BRICS countries, the significance of competition policy in these globalized economies prompted a certain degree of co-operation and experience sharing. The paper analyses 
the actual and potential contribution of the BRICS to overcoming or shifting the international fragmentation of the competition law. The overview of the current BRICS initiatives and cooperation should provide a better understanding of the BRICS approach towards the role of competition law, the substantive and procedural competition rules as well as the international enforcement cooperation. The paper is an attempt to understand whether the BRICS could potentially become an alternative multilateral platform for the international dialogue on competition law cooperation.

Presenter

AlexandrSvetlicinii - University of Macau

North by North-West? Decolonizing (Constitutional) Law, Recolonizing Legal Imagination

'What would a Global South perspective to (constitutional) law look like? When postcolonial, decolonial and other Global South jurists confront this question they never take it literally. This presentation argues that they should. In doing so, they should also attempt to answer a set of accompanying questions: What else, beyond 'perspectives' and 'vantage points' is there to the practice of envisioning? What could or should be envisioned differently? How does 'looking like' relate to the polemical, affective, disciplinary, and rhetorical dimensions of our imaginations? These questions, pardon the pun, stare us in the face, as the very term 'Third World' demonstrates itself; the concept, an ideological shorthand, or battle-cry which wouldn't be able to exist without also existing as a picture-of a World within a World somewhere, co-existing with two others, wanting to become, as Sauvy said, 'something'. To confront this 'something' not simply as a comparative constitutional scholar but also as the practitioner of imagination is to be reminded that no matter how we answer the questions of what /are/, or what /ought/, or what /could/ certain concepts, phenomena, and frameworks look like, or be understood, we will always end up with the question that underpins them all: what are they for? What do we need them for?

Presenter

Zoran Oklopcic - Carleton University

\section{Session IV-}

Chair - Edna Raquel Hogemann

Discussant: Lucia Frota Pestana de Aguiar Silva

A Complex Representation of Law: A study of Legal Consciousness in Venezuela. 
The primary objective of this research was to understand what a group of Venezuelans think about Law; their opinions about legal norms; and, more specifically, the meanings they have built around the Legal System. I focused my research on 100 clients of a Community Legal Service at the Universidad Central de Venezuela; mainly low-income that were looking for legal assistance. Contrary to what it could be thought, the significant deficiencies of the Venezuelan Legal System have created not an unstructured and precarious way to understand the Law; but, instead, an incredibly complex way to represent it. In spite of the diversity that was registered in the legal representations, two cultural features were identified in all the interviews: the multidimensionality of Law, and their multiple causalities. The Law in Venezuela, according to Venezuelans, happens and is explained by the complex conjunction of real and unreal factors. This way to represent Law cannot be understood as an expression of their lack of legal knowledge, or as a pre-modern thinking. On the contrary, it is the result of a complex way of thinking that has led them to understand legal actions, not as an exclusively modern or rational expression, but as a multidimensional reality with multiple causalities; where certainty is no longer an essential component of Law. Therefore, to Venezuelans, it is not awkward relating to Law as an act of faith.

Presenter

Irene Torres-Arends - Universidad Central de Venezuela

\section{The neoliberal diagram in Latin America: power relations and subjectivation processes into the political reconfiguration of judicial power}

In this paper I propose to problematize the role of judicial power in Latin America considering Foucault's works on power relations developed from 1973 to 1980, centered on neoliberal governmentality. Far from considering the judicialization of politics as the natural result of the democratization of Western societies, this particular approach on judicialization of politics in Latin America may contribute to understand why -and howwas it possible in the 1990's the emergence of the new role of judicial power all over the region, including Argentina. I am especially interested in exposing the multiple correlations between judicialization of politics itself and the power relations diagram and subjectivation processes that take place into neoliberal governamentality. In this presentation I will show which were some of these strategies and agencies that took place in the 1990's, in Argentina and specially in Mendoza, allowing or even promoting a reconfiguration of political role of judicial power. My contribution focuses not only on the singularity of the Argentine case, but on the potentiality of the Foucauldian perspective to understand our contemporaneity.

Presenter

Luciana Alvarez - Universidad Nacional de Cuyo/ CONICET 


\section{Judicial Discretion in Child Support Enforcement Court}

Child support enforcement court lies at the intersection of family law, welfare, and the criminal justice system. In child support enforcement court, nonresident parents face being held in contempt of court and incarcerated if they owe child support debt. Contempt for child support nonpayment blurs the line between the civil and criminal justice systems, constituting part of the "shadow carceral state" (Beckett \&Murakawa 2012), where civil entities acquire the capacity to detain. Most research on judicial discretion has focused on criminal courts, and most research on judicial discretion for child support has focused on the establishment process. This paper aims to bridge the gap between these two literatures by examining how judicial discretion operates in child support enforcement court. Drawing on field observation of 250 child support enforcement hearings in two jurisdictions, this paper examines the role of judicial discretion at three decision points in the life of a child support enforcement case. The first is whether or not a judge finds a parent indigent, and eligible for a court-appointed attorney. The second is whether or nota judge is willing to lower the bond on which a parent is held while awaiting his child support enforcement hearing. The third is whether a judge gives a contemnor another chance to pay down his debt before ruling that he serve out his sentence. Each of these decision points have real world consequences for parents and families.

Presenter

Elizabeth Cozzolino - The University of Texas at Austin

\section{Legal Subjectivity: Beyond the Exclusionary Figure of the Human}

Western law is built on human subjectivity. Such a humanist focus relies on the persistent idea that humans are the supreme actors, distinct from nature and animals. The concept of the human has hence been constructed in stark opposition to the nonhuman and, it is presumed, if largely implicitly, that there ought to be one type of subject, and one kind of human. As this paper demonstrates, this has had various problematic consequences. The nonhuman has been excluded from the realm of law and, perhaps paradoxically, large parts of 'humanity' are excluded as well. This last point is particularly noticeable in the context of refugees and migrants, who are often dehumanized and objectified by the very system that is supposed to offer them protection. However, if the 'Other' is marked as different, it only appears as such in relation to a purportedly neutral subjectivity. It is because we try to fix and categorize the human that a difference is produced, and also that objectification - even the idea of 'inhumanity' - becomes possible. This paper points to the limits of the figure of the human. It also argues that international human rights law, and Western law more generally, will have to go beyond the currently dominant concept of the human. Particularly in the context of refugees and migrants, international human rights law could greatly benefit from integrating a post-humanist perspective. 
Presenter

Elisabeth Roy Trudel- Concordia University

\section{Against Animal Ethics: Preliminaries for a Law of Animal Liberation}

Legal systems around the world have recently experienced a peculiar loosening of jurisprudential categories. Notions of legal object and legal subject, of person and property, have been shaken by the emergence of concerns about the legal status of animals. The "animal question", as it is referred to in the Humanities, has made its way into a variety of policy initiatives, including constitutional reforms and sweeping reforms of property law, all unified by a common concern for the status and well-being of animals. This paper proposes a critical reading of this transversal reformist wave as an example of successful ideological capture of what should constitute a revolutionary proposition for all liberal constitutionalist legal systems. In particular, it argues that a major influence on this wave is exerted by the academic and professional field of "animal ethics", which has decisively informed the direction and structure of legal reforms. Given the urgent political moment that those legal changes represent for social movements involved in animal rights causes, specific marginal legal arguments proposed in the midst of the general trend of animal-welfarist initiatives have to be highlighted and further developed, most notably to link animal-rights legal reforms with other progressive and emancipatory causes and campaigns.

Presenter

Alejandro LoriteEscorihuela- Universitédu Québec à Montréal

\section{Civil Litigation in Black and White: Black Newspapers and the Shaping and Transmission of Black Legal Culture under Jim Crow}

My dissertation examines civil suits filed by African Americans against white individuals and companies to explore what I believe is a relatively common, but understudied phenomenon; black people suing individual whites and private companies for incidents involving potentially racially motivated violence under Jim Crow (18801952). In a region where white prosecutors rarely brought charges against whites for racial violence or companies for neglecting African Americans, and where criminal statutes provided few specific protections against racially motivated violence, some currentblacks found remedies in areas of civil law that offered victims a legal remedy or civil justice, however partial, for racially motivated violence. But how did these plaintiffs know that they could bring suits or which causes of action to sue under? The paper that I am proposing for the LSA annual meeting will come from my research on black newspapers' coverage of black civil (damage) suits against white individuals and private companies for potentially racially motivated violence. I argue that black 
newspapers played an important role in the shaping of and transmission of black legal culture under Jim Crow. These papers serve as a network of legal knowledge leading up to and following the founding of the NAACP and its Legal Defense Fund. This paper builds upon work that I have workshopped at the ASLH's Student Research Colloquium, and will come out of research for the second chapter of my dissertation.

Presenter

Myisha S. Eatmon - Northwestern Univeristy

\section{Constitutional Theory Development in Asia and the Americas}

Societies in Asia and the Americas may seem to have nothing in common given their particularities; however, many countries in these two regions share similar historical and political experiences (e.g. dictatorships, revolutions, democratic mobilizations, civil rights or human rights problems, corruption etc.) and interact more and more pushed by economic and cultural globalization. Nevertheless these geographically diverse societies, although very different in their current legal and political cultures, may also share constitutional and democratic values. This session intends to bring together scholars engaged in studying the evolvement of constitutional features, either regarding constitutional law or constitutional theory, related to these regional foci.

\section{Session I}

Chair:Rafael Mario Iorio Filho - Universidade Estácio de Sá e INCT-InEAC

Discussant:Denis De Castro Halis- Faculty of Law / University of Macau

\section{Presidential Calls to Congress to Overrule Supreme Court Decisions}

From 1953-2017, presidents have discussed U.S. Supreme Court decisions in more than 900 public speeches. In speeches involving the Court's decided cases, presidents can praise or criticize the Court's decisions. When they denounce the Court's opinions, they frequently call on Congress to take action to remedy the effect of those decisions, such as introducing a constitutional amendment or passing legislation. In this paper, we examine the frequency with which presidents make such calls to Congress, their motivations for doing so, and whether Congress responds by taking action to alter the impact of Court's decisions. We draw on an original database of all presidential speeches regarding Supreme Court decisions from the Eisenhower to Obama administrations and information on congressional efforts to curtail the Court. Our theory 
is developed from scholarship on the coordinate construction of the Constitution, the separation of powers, presidential speechmaking, and the impact of Court decisions.

Presenter

Paul Collins -University of Massachusetts Amherst

Non-Presenting Co-Author

Matthew Eshbaugh-Soha- University of North Texas

\section{Real and Notional Claimants in Constitutional Litigation}

Scholars often categorize constitutional review in terms of either abstract or concrete review. Academics tend to refer to these categories because they help draw out different or competing approaches to judicial review in constitutional cases. Concrete review is thought to involve deciding cases on the basis of a defined factual matrix, while abstract review is thought to involve providing a legal opinion in the absence of such a matrix. But this distinction is increasingly breaking down, if it was ever meaningful to begin with. Constitutional litigation, whether commenced in abstract or concrete form, brings a range of individuals and their stories before the courts. What are the implications of these changes in the mode of constitutional adjudication? Can courts successfully navigate the complex dynamics of constitutional cases that involve differently situated plaintiffs, or do these modes of analysis result in errors and/or unfairness? Can they be said to expand access to courts for equality-seeking groups or are they a poor substitute for better-coordinated, legislative law reform efforts? I examine some of these questions in this paper.

Presenter

Vanessa MacDonnell - University of Ottawa Faculty of Law

\section{Impeachment by Judicial Review: Israel's Odd System of Checks and Balances}

One of the most intriguing questions in contemporary constitutional theory is why are political power-holders willing to bestow power on courts and to acknowledge their autonomy. Constitutional theorists offered many explanations for this phenomenon, such as 'insurance theory' or theories of blame shifting from politicians to courts. In the current paper, I seek to offer an additional explanation. It focuses on a doctrine that the Israeli Supreme Court (ISC) developed since the early 1990s under which the Court removes office holders from their position by ordinary judicial review proceedings. This doctrine is not founded on any formal constitutional settings, but it had significance influence on the relationships between the judiciary and the political branches, as it was the basis for the removal of several major political figures including ministers and top bureaucrats from office. This practice of 'impeachment' by judicial review is unique to 
Israel. Hence, it has hardly been studied by the comparative literature. It is, however, extremely common and influential in Israeli constitutional and political life. It also enjoys massive support on behalf of legal elites and the general public alike. I argue that one cannot understand the relationships between courts and politics in Israel without bringing this component into account. In the paper, I describe the development of this practice and its influence on the relationships between courts and politics in Israel.

Presenter

Yoav Dotan- Faculty of Law, Hebrew University Jerusalem

\section{What is an Article V Convention?}

A sense is mounting that the United States Constitution is at a crossroads. Twenty-nine states have applied to Congress to call a convention for proposing amendments. Article $\mathrm{V}$ provides few clues about how such a convention would work. My proposal, which builds on an essay that I have already begun, is to reexamine the meaning of the "convention" in the U.S. constitutional system. The dominant account can be traced to the work of Gordon Wood, who maintains that by the early 1780s conventions came to stand for the authority of the people outside government. Yet the U.S. Constitution has been amended twenty-seven times without once employing an Article V convention. Its most important additions, like the Fifth and Fourteenth Amendments, were proposed and ratified entirely by legislatures. Do they lack popular authority? Today, state constitutions, too, are amended overwhelmingly by legislatures. My study of convention will focus on political pamphlets and early practices in American states. I argue that these sources show a real division of opinion about the distinction between conventions and legislatures, and that where conventions were employed the primary concern was corruption or self-dealing by a legislative body. Conversely, where constitutional design was thought to mitigate the danger of corruption, legislatures could be used to amend constitutions and give effect to popular sovereignty.

Presenter

Matthew Steilen- University at Buffalo School of Law

\section{Racist Election Campaigns and the Constitution}

Racist and xenophobic discourse in election campaigns is emerging as a difficult constitutional problem in Japan. If political speech is at the core of the protection of freedom of speech, we may have to vigorously guard racist election campaigns against government intervention. Japan, however, has the obligation under the International Convention on Elimination of All Forms of Racial Discrimination (ICERD) not to permit public authorities to promote racial discrimination. This paper attempts to lay out the balanced response to racist or xenophobic speeches and slogans made by candidates 
for public office under the Constitution of Japan, relevant statutes and case laws, and the ICERD.

Presenter

Junko Kotani - Shizuoka University

\section{Session II}

Chair/Discussant:

Rafael Mario Iorio Filho

Universidade Estácio de Sá e INCT-InEAC

\section{Constitutionalism in the Kingdom of Bhutan}

Buddhist principles played very important role in shaping Bhutan as a nation-state including the institution of hereditary monarchy. Bhutan remained isolated by choice until 1970s, and it virtually opened up to world in 1999. The Fourth King spearheaded the introduction of democracy guided by his concept of Gross National Happiness (GNH) which is deeply rooted in Buddhist principles of contentment, respect for all sentient beings, peaceful coexistence and tolerance. The constitution finds a special place for cultural values and Buddhism, while also respecting cultural and religious pluralism and the natural environment. Bhutan is now a 'democratic constitutional monarchy' - the King still has very important role to play in Bhutanese democracy. Critics from outside question the excessive power given to the King; however, the sentiment in Bhutan is completely opposite. The people see the King as the symbol of unity and ultimate protector. The role of the King as protector has now become one of the Bhutanese values recognized by the constitution. Except for few minor setbacks, the new system has worked very well for the past ten years.

Presenter

NimaDorji - Jigme SingyeWangchuck School of Law

\section{The State of Exception and Crisis Government: A Comparative Analysis of Mexico and Chile}

Crisis government in Latin Americas has been and will very likely continue to be central in the context of contemporary rising violence and security issues, natural disasters, unresolved socioeconomic inequality and democratic deficits. This paper offers a comparative view of the legal frameworks of such crisis governments in the cases of Mexico and Chile considering the multiplicity of legal forms at play in both 
countries such as emergency regimes, the state of siege, congressional delegations to the executive and various forms of the state of exception. We argue that Mexico and Chile are in opposite ends of the spectrum of legal applications of different forms of crisis government in the region: While Chile, since the recovery of democracy, has used constitutional "states of exception" such as the State of Catastrophe and the State of Emergency in the application of the exception, Mexico has avoided the use of its constitutional provision of the state of siege, and instead has appealed to an extra-legal form of the exception and congressional delegations to the executive power in security issues.To sum up, while Chile has used the legal emergency/constitutional dictatorship paradigm, Mexico has resorted to the extra-legal exception and the prerogative.

Presenter

Maria Victoria Crespo - Universidad Autónoma del Estado de Morelos-Universidad Nacional de San Martín

Presenting Co-Author

Claudia Heiss - Universidad de Chile

\section{Popular Constitutionalism and mechanisms of democratization of the decision making power in the new Latin American constitutionalism}

Since the development of the United States judicial review model, in the early nineteenth century, the world coexists with an expansion of the judiciary role, which now claims the responsibility of giving the last word about the constitution's meaning. This allocation of power brings a great number of criticisms in the field of Constitutional Law Theory and Political Philosophy and one of these challenges emerge from a body of constitutional literature recently developed in the United States, which is referred to as "popular constitutionalism", brought together by the common assumption that there is constitutional life outside the courts. This article compares three thesis about popular constitutionalism - Larry D. Kramer, Mark Tushnet and Jeremy Waldron - to understand why the power of determining the meaning of the constitution should not be with the judicial branch, but in the hands of the people. After a thoughtful review of their doctrine, the problem arises on how popular control of the constitution can become effective nowadays. To answer this problem, the article turns to the so-called new Latin American constitutionalism, a movement which seeks to confer greater power to citizenship in the decision-making process of important social and economic issues through innovative institutional models of popular participation. Thus, the article demonstrates how these new arrangements break with the paradigm of judicial supremacy and approach the notion of popular constitutionalism.

Presenter

Claudia Maria Barbosa -Pontifícia Universidade Católica do Paraná 
Presenting Co-Author

Sylvia Araujo - Pontifical Catholic University of Paraná

The Recent Decision of the Supreme Court of Bangladesh Nullifying the Government's Design to Curb the Independence of the Superior Judiciary and the Subsequent Scathing Attack on the Chief Justice: Addressing the Necessity to Prevent the Executive from becoming the Unlimited Master of the State

The Constitution of Bangladesh originally empowered the Parliament to remove judges of the Supreme Court on the grounds of proved misbehaviour or incapacity. However, the Constitutional Amendment of 1975 empowered the President to remove the judges of the Supreme Court in accordance with his own will. But in 1977, the extraconstitutional martial law regime changed the method of removing the judges of the superior judiciary. This procedure stipulated that a judge of the Supreme Court could only be removed from office by the President on the recommendation of the Supreme Judicial Council, which was to be composed of the Chief Justice and the two next senior judges. However, this method of removal was dispensed with by the Constitutional (Sixteenth Amendment), 2014. This amendment once again vested the power to remove judges in the Parliament. The real reason behind this amendment was to curb the independence of the judiciary by seeking to bring it under the control of an all-powerful executive. For the present Parliament of Bangladesh is completely subservient to the executive. However, the Supreme Court in July 2017 in a landmark case declared the Sixteenth Amendment ultra vires the Constitution. This decision outraged the government, which forced the Chief Justice to go on leave and subsequently instituted 11 charges of graft and money laundering against him. The objective of this paper is to prevent the executive from becoming the 'unlimited master of the state'.

Presenter

M Ehteshamul Bari - Deakin University

\section{Session III}

Chair:Fernanda Duarte - UNESA e INCT/InEAC/PROPPI/UFF

Discussant:Rubens Beçak - University of Sao Paulo

\section{Abusive Separation of Powers in India}

This paper tells the story of the legal and political aftermath of an iconic decision in India: DC Wadhwa v State of Bihar. Delivered in 1986, the verdict had to do with the executive's authority to enact legislation. The Indian Constitution authorizes the 
executive to enact legislation provided certain conditions are met. Such legislation are temporary. Can the executive repeatedly promulgate the same ordinance? In Wadhwa, the apex court said no: Repromulgation negates the system of separated powers, and renders the legislature irrelevant. But a small window of exception was left open: In some cases, the executive could do so. The decision was an instant classic. Widely reported, it was, many felt, a victory of constitutional values. How has the executive performed since? Has it eschewed from re-promulgations? This paper looks at two levels of data. First, I study the frequency with, and the jurisdictional breath for, which Wadhwa has been cited as a precedent. Second, I look at re-promulgations since 1985. The data yields contradictory results. As a precedent, Wadhwa is a bright star. But the executive's performance though tells a different story. Re-promulgations continued well in the 1990s. The Union executive took to re-promulgations since the early 1990s. As a result, Wadhwa is a constitutional enigma. It is simultaneously a hallowed precedent, and an unenforced decision. Because of it, a constitutional norm and its flagrant violations endure side by side.

Presenter

Shubhankar Dam - University of Portsmouth School of Law

\section{Of Art and Order: the Constitutional Protection of "Good Traditions" and the Everyday Policing of Cambodian Culture}

Constitutional practice in Cambodia has largely been misunderstood or overlooked altogether. This can be traced to two assumptions common to understanding constitutionalism: that the idea is innately liberal, and that its practice must take place in courtrooms. Yet, despite a much-maligned judiciary, the Constitution is in fact central to the everyday politics of illiberalism in Cambodia, where constitutional vocabulary is used to both justify and challenge authoritarian rule. This is exemplified by the Ministry of Culture's 'Code of Conduct for Artists'; a seemingly innocuous document that drawing on constitutional provisions protecting "social order" and "Khmer traditions" has since been used to limit space for political expression, and to police the bodies of female musicians. Building on a year of fieldwork, including participant observation and over 45 semi-structured interviews, I examine the role of the Constitution in the state's policing of a narrowly defined "Khmer culture." Further, I investigate how the country's artists have responded, highlighting the strategies of everyday resistance used to escape censorship while operating in an increasingly globalised space, at a crossroads with foreign cultures. Thus, as well as posing a challenge to traditionally liberal understandings of constitutionalism, this paper introduces previously overlooked actors and new layers of ethnographic depth to the growing literature on constitutional practice under authoritarianism.

Presenter 
Benjamin Lawrence - University of Victoria

\section{Present and future of Constitutional Justice in Mexico: Why more constitutional control is not necessarily a better control?}

Since 1847, constitutional control in Mexico was based solely in the writ of amparo. However the limited inter partes effects of the writ of amparo led to a substantial constitutional amendment in 1994 which established abstract norm control (with ergaomnes effects) and constitutional controversies. The system was then intended to work as a concentrated European-Kelsenian model conceiving the Supreme Court as a Constitutional Court even though it maintained some attributions concerning legality. However, the system radically changed in 2011 when the Supreme Court issued the resolution Varios 912/2010 reacting to the Radilla ruling from the Inter-American Court of Human Rights. In the abovementioned resolution the Supreme Court changed its former case law to allow every judge to perform constitutional and conventional control, thus changing the system into a diffuse control type. Therefore, currently concentrated control mechanisms coexist with the diffuse judiciary review and the omnipresent amparo writ which allows to question any act, law or ruling to the Federal Judiciary and with local constitutional courts in Mexican federalist system. In this article I will explain why more constitutional control does not necessarily mean a better constitutional control. I will underline the problems caused by the multiple actors and different procedures through which is possible to perform constitutional control questioning thus the chaotic Mexican model.

Presenter

Mauro Arturo Rivera Leon - Supreme Court of Justice (Mexico)

\section{What role do "Saving clauses" contained in Commonwealth Caribbean Constitutions Play in the Relationship between Law and Society?}

In this paper, I will look at the role that "saving clauses" contained in the Commonwealth Caribbean constitutions play in the interaction between law and society in this region. "Saving clause" is a constitutional provision that insulates (saves) laws that were in force at the time of acquisition of independence by Caribbean countries from constitutional review. Existence of such clauses mainly poses problems when preindependence criminal laws are subject to judicial review. Mostly such laws concern serious jurisprudential and social problems, such as capital punishment or criminalization of homosexuality among consenting adults in private. Such laws are now considered as serious violation of human rights and the Constitution itself. However, they imply another serious jurisprudential problem. Savings clause preserves colonial legislation, thus, creating an obstacle for development of post-independence local law, and becomes a serious obstacle for legal reforms that West Indian societies 
may want to implement in their legal systems. This problem will be addressed in this paper.

Presenter

AsyaOstroukh - University of the West Indies

\section{Popular constitutionalism in today's USA: Activist praxis, strategic necessity and structural change}

Social movement campaigns for constitutional reform are a significant feature of contemporary politics in the United States, involving millions of citizens of varying political beliefs in efforts to amend the federal constitution to restrain corporate power, require a balanced budget, protect voting rights, guarantee equal rights, and abolish the electoral college. In recent years a majority of Americans as well as a majority of states have voted in favor of some of these measures. Such widespread engagement in activist constitutionalism represents something new for the U.S. left in particular. From 1982 to 2000, progressive social movements campaigned on various terrains; constitutional reform was not prominent among them. In this study, I rely on over 30 semi-structured interviews as well as movement archives and secondary sources to investigate what led a wide variety of activists and organizations to begin to reorient their work toward constitutional and other democratizing reforms. I show that the activist turn toward democratic structural and constitutional reforms occurred in spite and not because of political conditions, resource capacity or strategic capacity. Instead, it was an emergent sense of the strategic necessity for structural reform as a response to the structural adjustment programs of the 1980s and 1990s that led activists to construct the democratic constitutionalisms of the present.

Presenter

Ben Manski - University of California, Santa Barbara

\section{Session IV}

Chair:Jairo Lima - University of Sao Paulo/Brazil

Discussant:Flavia Lima - UNICAP/Brazil

\section{Laboratories of Democracy? State Constitutional Antecedents to Federal Constitutional Rights}

In 1932 Justice Louis Brandeis proposed that American states test constitutional policies prior to their adoption by the federal government. More recently John Dinan, Robert F. Williams, Alan Tarr, and Emily Zackin have suggested that state constitutional experimentation addresses and sometimes anticipates national trends. But how accurate 
is this "laboratories of democracy" thesis? That is, how often and why do state constitutional proposals anticipate federal ones? This paper answers this question with an original dataset of all rights provisions in proposed state constitutions from 1776 to the present, and all proposed and ratified federal rights amendments since 1788. The paper finds that state constitutional revision on a rights issue often precedes federal rights proposals and the ratification of federal rights amendments, including the Bill of Rights, the Reconstruction Amendments, and the Nineteenth Amendment. The paper closes by proposing causal and particularly social movement mechanisms to explain this.

Presenter

Robinson Woodward-Burns - Howard University

Presenting Co-Author(s)

Stephan Stohler- SUNY, University at Albany

David Bateman - Cornell University

\section{Comparative Plenary Powers}

What does it mean for the President to possess "plenary power"? Appearing in contexts as varied as immigration law and presidential pardons, plenary power is often characterized as a source of boundless power to the holder, or alternatively, as a nonjusticiability doctrine. Considering recent litigation over the President's travel bans and the President's controversial pardon of Sheriff Arpaio, and drawing on traditional principles of constitutional analysis, this article argues that "plenary power" is best understood as great deference, but not complete non-justiciability.

Presenter

Shalini Ray - University of Alabama School of Law

\section{The illusion of the Directive Constitution}

The present study adopts as object of analysis the Brazilian constitutional design forged from the Constitution of 1988, in order to discuss the insufficiency and the theoretical impossibility of the constitutional dirigisme. The model of the directive Constitution has been severely criticized over the years for bringing in its scope a series of social aspirations that can not be fulfilled, and for bringing in the constitutional text a series of programs and goals that are considered as utopias, incapable of being concretized by the State. In June 2013, Brazilian society took the streets to protest, the Federal Constitution of 1988 returned to be questioned, but this time, there was no single claim, in short, the effectiveness of our constitutional text was pleaded. They questioned the right to health, 
education, access to justice, intellectual freedom, isonomy, among many other constitutionally guaranteed rights. Faced with the symbolism of the constitutional text, it becomes obvious that there is an urgent need to rethink constitutional dirigism, as it currently exists in Brazil, and new premises for better institutional designs, in order to concretize the guarantee of fundamental rights, the democratic State of Law, Separate and harmonious Powers and the good functioning of the Public Administration, in a systemic and efficient dimension. KEY WORDS: Directive Constitution. Dirigism. Institutional designs. Systemic dimension analysis.

Presenter

Daniel Oliveira - UFRJ/Brazil

PresentingCo-Author: ThayaneSarges- Universidade Federal do Rio de Janeiro/ FND

\section{Local referendums as devices for enhancing participatory democracy}

Representative democracy is in crisis today. It is said that we live in a civic dessafection age, whereby individuals are passive regarding public affairs (Taylor 1991, Galli 2013). People are incredulous with democracy, because democracy cannot fulfill their own promises (Ranciere 2006). At the same time we appreciate that political involvement has raised through social movement. After the deliberative turn, the solution given by western democracies has been to create participatory and deliberative mechanisms (Bohman 1998). An example is the referendum, which has been largely studied to national level (Altman 2010, Tierney 2012). However, the study of local referendum is scarce as it is the case of local democracy in general (Schiller 2011, Loughlin 2001). The goal of this paper is to argue how local referendums can enhance citizen participation and by so doing improve quality of democracy. To do so, I will explain the potentialities of multi-level democracy and European conception of subsidiarity. Also I will argue how it is possible to overcome main critiques against direct democracy, by classifying democratic and undemocratic referendums, and describing which elements of a local referendums process need to be assured.

Presenter

Leonardo Cofre - Universidad de Chile

\section{Stealth Theocracy}

When theocracies are born, they tend to emerge through constitutional revolution, not evolution. This Article explores a subtler phenomenon of constitutional transformation involving the expansion of religion's place through less transparent means of constitutional change. The Article offers an account of this phenomenon of "stealth theocracy:" the fundamental alteration of a constitution's religious or secular character 
through informal judicial and political engagement, rather than through formal amendment or replacement. Using Malaysia as a case study, this Article examines the elevation of Islam's constitutional position, which has shifted the Malaysian state from a secular foundation to an increasingly religious constitutional order. Courts are main agents of this phenomenon, using judicial mechanisms-like jurisdictional deference to the religious courts and judicial Islamization of the secular courts-to fuel a profound shift toward a more theocratic constitutional order. This Article challenges the prevailing view in the scholarship of courts as secularizing bulwarks against the effects of constitutionalizing religion. It tells an inverse story: courts serve as theocratizing forces that act to expand, not limit, religion's public role. This account also has broader implications for constitutional change, constitutional history, and constitutional identity.

Presenter

Yvonne Tew- Georgetown University Law Center

\section{Criminal Justice in Asia and in the Americas}

This session covers legal and social issues in Asia and the Americas, focusing on work related to Criminal Justice in these regions. Examples might include discussions of contemporary political or legal challenges faced by governments or social groups related to punishment, analyses of emerging trends in criminal legal theory as they are related to Asia or the Americas, and/or projects that concentrate on particular legal or social problems endemic to societies in either region regarding crime and punishment. Discussions related to International Criminal Justice are welcome as well.

\section{Session I}

Chair:Rafael Mario Iorio Filho - Universidade Estácio de Sá e INCT-InEAC

Discussant:Fernanda Duarte - UNESA e INCT/InEAC/PROPPI/UFF

\section{The defense in international legal assistance in criminal matters}

The presente work has as main scope to verify the applicability of the equality of arms in international legal assistance in criminal matters. Given this premise, it attempts to analyze international and national specific regulations that must be taken into consideration by the states that call themselves democratic and, above all, of law, in order to ensure an equitable criminal prosecution, from the perspective of the principles of adversary proceeding, full right to defense and the equality of arms. Therefore, we carried out a literature review, from which it was sought to elide reductionist view of international legal assistance, in the sense that we cannot forget that, on the other side of 
the punitive function of the State, there is a person with numerous safeguards and rights provided historically. The first chapter deals with the international legal assistance in three aspects: historical, applicable principles and analytical-descriptive. In the second chapter, we study the principles and guarantees inherent to the due process of law, which can not be suppressed, because it is enshrined human rights. The third chapter addresses the instrumentality derived from the theoretical leather built in previous chapters. Thus, the production of evidence in transnational criminal proceedings is examined under the bias of international legal assistance, going up by the reasoned direct assistance mechanism of bilateral agreements and by attempts to balance the system, among others

Presenter

Viviane Dallasta Del Grossi - Defensoria Pública da União

\section{A critical look at globalization and transnational crime}

The globalized world has created a paradox between sovereignty and human rights. Today there is a need to typify new crimes that have emerged as the effects of globalization. Some of these effects on delinquency are reflected in the dogmatics Penal, in the symbolic Penal Law and in the Criminal Law of the Enemy. The process of globalization also influences the extension of human rights as the fundamental value necessary to the liberal state to rescue human dignity to all the people around the world. The proliferation of attacks around the world brings asymmetric threats (terrorism), which through cyberspace facilitate the proliferation and anonymity of illicit acts. The situation is aggravated by the ramifications of various types of unpunished terror. It is necessary to have a globalized Criminal Law that takes care of this transnational and organized crime, which undeniably requires a number of adaptations, especially in human rights groups of different cultures and human behaviors group civilizations that should be criminalized and punished. It is therefore necessary to reflect on the other side of globalization and its social effects. The construction of a contemporary of intrinsic Human Rights must be analyzed and studied legally in the new and bold concept of global citizenship

Presenter

PatricyJustino - Universidade Estácio de Sá

\section{The Price of Justice Questioning the Trust Fund for Victims of the International Criminal Court}

When the International Criminal Court (ICC) was created, one of the most important lessons learned from earlier international tribunals was the need for a much stronger role of the victims. The result was not only far better protection of witnesses but also an 
astonishing amount of victim participation rights during all stages of the criminal process. One of the most ground breaking innovations of the new Court, however, was the establishment of the Trust Fund for Victims (TFV). Besides being responsible for reparation payments to victims, this body is unprecedented because it provides funds even before the trial has ended. The TFV is therefore repeatedly praised for supporting hundreds of thousands of victims without the need for awaiting a conviction after years of trial. This paper conversely, wants to draw attention to the various weaknesses of the Fund. It will demonstrate that the TFV not only diverts resources from the ICC but moreover dilutes the already difficult to define objectives of the Court. It will be argued that the TFV raises serious questions about the function of the Court and its role in the international community. While the immediate material help for the most vulnerable must be welcome, this paper identifies the underlying theoretical and practical difficulties which will undermine the interests of the victims in the long run.

Presenter

Regina Rauxloh - University of Southampton, Law School

\section{Session II}

Chair/Discussant:Bruno Rezende /UNESA - Brazil

\section{Who Judges? Designing New Jury Systems in Japan, Taiwan, South Korea, and Spain}

Jury/lay judge systems vary markedly across different countries in their design, in particular in the extent to which they grant real powers to jurors/lay judges. Why do some countries transfer greater powers over verdict and sentencing from professional judges to citizens, whereas others choose to leave more of those powers in the hands of the professional judges? To shed light on this question, this paper examines four developed democracies where the question of introducing new jury/lay judge systems became a significant issue on the political agenda after 1990: Japan, Taiwan, South Korea, and Spain. Drawing on quantitative content analyses of fifty years of Japanese parliamentary debates as well as careful case studies of the four country-cases, the paper shows how differences in the "new left" orientations of leftist parties and the relative strength of those parties within the overall party system crucially shaped the extent to which power was transferred from professional judges to ordinary citizens.

Presenter

Rieko Kage- University of Tokyo 


\section{Making Prosecutors: Stories Of Taiwan And Beyond}

This paper seeks to address a gap in transnational research on prosecutors through the lens of Taiwanese criminal justice system. Studies of prosecutors have largely focused on the legal structure within which prosecutors operate as well as their performance within those structures. Little attention has been paid to how prosecutors experience their professional role throughout the ongoing process of career development. This paper examines the development of prosecutor's professional role and their motivation to do their work throughout different stages of their careers. I employ a career-path mapping method that seeks to capture prosecutors' performance and role-construction over time. By examining the dynamics of prosecutors' professional identities and performances, I aim to demonstrate that individual prosecutor's accounts are deeply embedded in the office culture, social context, and relations within the profession. This paper surveys the work environments and self-images of Taiwanese prosecutors through 72 interviews and field observation. I explore the evolution, structure, and practices of the Taiwanese prosecution in relation to the legal system and the society in which it is embedded. I focus on four aspects of Taiwanese prosecution: (1)prosecutor's function;(2) organization of prosecutor's office; (3)prosecutors' professional ideology and motivation;(4) interactions between prosecutors and other actors, including the police, defense attorneys, judges, and media.

Presenter

Shih Chun Chien- Stanford Law School

\section{Miscarriages of Justice: Wrongful Conviction Cases in Canada}

Numerous public inquires and reports in Canada have brought an alarming number of wrongful convictions to light, but there has been little in the way of systematic examination or tracking of wrongful conviction cases across the country. Innocence Canada (2017) examines its own cases, providing a structured explanation of the causal factors related to each wrongful conviction in their system. As well, valuable recommendations for how to prevent future wrongful convictions have been made during each of the half dozen government inquiries into high profile cases of wrongful conviction. Notwithstanding these efforts, a more comprehensive examination of national cases is needed to better understand the Canadian landscape of wrongful convictions. To begin this process, the current paper attempts to shed some light on the known exonerations that have occurred in Canada. Using a variety of sources (e.g., Inquires, Innocence projects, internet searches), 69 Canadian cases of wrongful conviction were identified. We examine the profile of the exonerees (e.g., gender, age, race/ethnicity), the profile of their cases (e.g., charges, sentence, timeframe from conviction to exoneration), and the factors that contributed to the wrongful conviction. In addition, whether or not the exoneree received financial compensation for the 
wrongful conviction (and if so, what was the monetary amount) and whether the exoneree received an apology (and if so, its source) was also noted.

Presenter

Regina Schuller -York University

Non-Presenting Co-Author(s)

Kimberley Clow- University of Ontario Institute of Technology

Caroline Erentzen- York University

\section{Innovation for the worse: Brazilian's criminal legislative reform (1984-2017)}

Between 1990 and 2017, Brazil's prison population grew from 575 per cent, that means, from 90,000 to over 650,000, turning Brazil the world's third largest prison population. However, this is not an issue for many congressmen who endorse most proposals, which impacts prison population but denies substantial increase in budgetary resources to the expansion of the prison system. This paper shows the results of empirical research that analysed 300 bills presented by Brazilian congressmen from 1984 to 2017 related to the use of imprisonment. The research aimed to organize the main proposals of these bills and also identify the arguments evoked by congressmen to defend their bill's approval by their peers. We noticed that more than 90 per cent of bills pursue a criminal policy under which long-term prison regimes are imposed and abolish prisoner's legal benefits, disregarding internationally acceptable standards, which are not provided due to overcrowding. Supporters of the legislation argue mainly that this kind of measure can end the sense of impunity. Less than 5 per cent of bills have proposed measures of early release from prison. This paper can bring an intellectual contribution to the comprehension of the main arguments presented by congressmen might back up laws that contribute to the increase in prison population, disregarding any international standards and/or structural causes that could lead to a short-term increase in Brazil's prison population.

Presenter

Carolina Cutrupi Ferreira - Fundação Getúlio Vargas/Brasil

\section{Current legal issues in Asia and the Americas}

This session covers legal and social issues in Asia and the Americas. The focus will be on work related to current trends in these regions. Examples might include discussions of contemporary political or legal challenges faced by governments or social groups, analyses of emerging trends in legal theory as they are related to Asia or the Americas, 
and/or projects that concentrate on particular legal or social problems endemic to societies in either region.

\section{Session I}

Chair: Rubens Beçak - University of Sao Paulo

Discussant: Jairo Lima - University of Sao Paulo

The Impact of State Religious Freedom Restoration Acts: An Analysis of the Interpretive Case Law

The arguments for and against RFRAs have been fraught with worst case scenarios. There has been no detailed study of RFRAs utilizing the best body of evidence indicative of their impact, specifically, federal and state case law. This paper provides such a study. The paper's hypothesis is that RFRAs have been far less effective and harmful than supporters and opponents contend. Rather, RFRAs have been successfully utilized by a diverse array of claimants in a limited number of circumstances. The paper measures the impact of RFRAs through analysis of the following data points: (1) filing dates; (2) the identity of the parties; (3) the subject matter of the claims and whether they were offensive or defensive; and (4) the outcomes of each claim. Discussion of each data point is preceded by an expected observation and concludes with an analysis of the actual results. The sample consists of 171 court opinions, specifically, 99 federal court opinions and 72 state court opinions. The selected cases are from sixteen of the twenty-one states that have adopted RFRAs since 1993. The year 1993 was selected as the starting date given that the first RFRA was adopted in that year. The end of calendar year 2015 was selected as the concluding date. Opinions announced during this period of time were included in the analysis if they addressed a RFRA claim either from a procedural standpoint or on the merits.

Presenter

Lucien Dhooge - Georgia Institute of Technology

\section{Testing Public Agency Responses to Citizen Reports: A Field Experiment}

This study examines the effects of ethnicity and apparent English proficiency on access to state agencies in the United States. Specifically, it assesses how public assistance fraud control entities respond to complaints of welfare fraud from members of the public, and differences in those responses based on the characteristics of the people making the reports. It asks if there are differences in the likelihood of a report being taken seriously by fraud control authorities if it comes from a person who is ostensibly Latina or ostensibly white, and if there are differences if it comes from an ostensible native English speaker or an ostensible non-native English speaker. Using a field experiment design, the study will test how fraud control entities respond to pretextual fraud reports with systematic variations in reporter names and report text to indicate 
white vs. Latina ethnicity and native vs. non-native English speaker status, respectively. Receipt of follow-up emails from state agencies will indicate agency interest, and nonresponse will indicate non-interest. The project has full approval from University human subjects and research oversight officials. Data will be collected in the autumn and winter to prepare for presentation at LSA. The results will shed new light on inequalities in access to state agencies for members of different demographic groups, and reveal how systematic differences in the origination of welfare fraud control cases shape system outcomes.

Presenter

Spencer Headworth - Purdue University

Non-Presenting Co-Author

Viridiana Rios - Purdue University

Posthumanism: redefining the human and non-human condition in a speakable and non - speakable world using Brazilian's Constitution as a model

Posthumanism is a very rich term meaning the result of the contemporary need to redefine the human condition, joining together deconstructionists, animal studies, and environmentalists, discussing how man has maintained the privileged place among the animals. In Brazil the constitutional law protects the environment and the future generations. The Speciesism is a very important part of the Posthumanism, investigating the geological time of the Anthropocene and facing the degradation of ecosystem services and the erosion of the planet's capability to absorb our wastes. The Anthropocene suggests that we need to alter our relationship with the planet as a complex form of interconnectivity. If humans still live full of racism, sexism and Speciesism, how could humanity deal with exotic difference as a robot or an alien? Cross conjugating speakable and non - speakable language. It's urgent to disregard species in favor of the value of the bio political framework. The right to live is a complex field and for which the human animal vocabulary we have inherit is insufficient . Hanna Arendt says it is a human privilege to make new beginnings. It's time now.

Presenter

Lucia Frota Pestana de Aguiar Silva - Universidade Estácio de Sá

Non-PresentingCo-Author - André Gustavo Corrêa de Andrade

Universidade Estácio de Sá

Negotiating Gender, Community and Citizenship: The Harmonization of Religious Family Laws in India

Contrary to popular perception, religious family law in India is a dynamic space. In the last twenty years, this space has witnessed incremental change through: (a) legislative reform of particular religious family laws, for instance, changes in the Christian family 
law; (b) judicial interpretation applying secular standards to limit the scope of religious laws, for instance, the case of Muslim law of polygamy, divorce and maintenance; and (c) enactment of secular family laws that apply to all religious groups, for instance, those pertaining to child marriage and domestic violence. This paper has two objectives. First, it argues that the Indian case of religious family law reform can be understood through the lens of "harmonization" - a familiar concept in the comparative law literature, which denotes the creation of uniform standards among different entities while retaining their distinctiveness. The second objective is to illustrate this legal phenomenon of law reform through harmonization, by examining the third development listed above. The paper examines the ways in which litigants from different religious groups claim reliefs under the secular laws governing domestic violence and child marriage; how such claims are resisted; how the judges resolve the conflicts between religious and secular laws; and finally, how all these factors cumulatively contribute to the dynamic character of religious family law in India.

Presenter

Saptarshi Mandal - Jindal Global Law School

\section{The Distance Between Us: Establishing Rural Remoteness as an Analogous Ground of Discrimination}

The funding of religious education in rural Saskatchewan in Good Spirit School Division v Christ the Teacher Roman Catholic Separate School Division No. 212 and The Government of Saskatchewan has raised complicated issues on the use of the notwithstanding clause. It also brings into focus a marginalized issue in Canadian equality and anti-discrimination law: discrimination on the basis of geography. Using the Corbiere test from the Supreme Court and academic critiques, this presentation argues that rural remoteness should be established as an analogous ground of discrimination. The presentation addresses the challenges in defining rural remoteness and how it intersects with the enumerated grounds in s. 15 of The Charter. It then assesses how this can positively impact the equality landscape in Canada. There are significant advantages to recognizing that rural life is an immutable characteristic and that decision making is often based on stereotypes of rural and northern life. It can be a tool to empower individuals and a method to overcome government apathy to rural and northern communities. Specifically, it requires the government to demonstrate with evidence-based reasoning its choices and decisions that negatively impact rural and northern communities. This proposal can ensure that equality law in Canada is sensitive to the needs of all people.

Presenter

Meghan Campbell - University of Birmingham

\section{SessionII}

Chair:Ronaldo Lucas da Silva - Universidade Estácio de Sá/CRN01 
Discussant:Fernanda Duarte - UNESA e INCT/InEAC/PROPPI/UFF

\section{Explaining Non-Dissenting Judicial Opinions: Collective Decisions And Institutional Theory}

This paper has as its object the investigation of collegiate decisions and necessary requirements for they produce better results. It is intended thereby indicate the precautions to be considered for prescribing appropriate institutional designs and discuss the thoughtlessly recommendation of collegiate institutions without a proper reflection of institutional designs. The self-centered decisions, that despise collegiality and emphasize the individuality of the decision makers, are problematic, but in some circumstances they might be second-best decisions. The hypothesis is based on evidence that collegial courts and agencies not always achieve betters decisions, and self-centered decisions should be occasionally the best protocol to follow.

Presenter

Igor De Lazari - Universidade Federal do Rio de Janeiro

\section{Institutional Dialogues: An Analysis Of Complementary Institutional Capacities As A Mechanism Of Interpretation And Opposition To The Social Dumping.}

We intend to analyze international norms elaborated by different centers of normative production, their possibilities of being constituted as instruments of confrontation of social dumping. In the context of institutional theory, considering the interaction of a plurality of relationships (political, social, economic, institutional) that contribute to the outcome of judicial decisions, we adopt A. Vermeule's conception of systemic effects and emerging properties - the decisions adopted institutional actors should analyze the risks, undesirable consequences, to avoid them or to minimize them. The Law 13467/17 can't be conceived as democratic. There have been opposing manifestations of different institutional actors with the capacity to assess the risks of systemic imbalances in the application of this latest legislation, among these National Association of Magistrates and Labor Prosecutors. It's possible to interpret the reform in the light of the Constitution, the International Conventions and the ILO Declaration of Fundamental Rights of 1998, the norms adopted by the transnational corporations that operate in the country, their respective codes of conduct and global framework agreements. Analyze the extent to which the institutions that adopt them have the potential to also participate in a possible institutional dialogue in the interpretation and application of the law and the realization of global labor rights.

Presenter

Daniele Gabrich Gueiros - Universidade Federal do Rio de Janeiro 
PresentingCo-Author

Verônica de Araújo Triani - Universidade Federal Fluminense

\section{The Internet is not a Public Park: A Critique of Packingham v. North Carolina}

In 1997, in Reno v. ACLU, the U.S. Supreme Court shaped the future of internet free speech law when it determined that as a medium, the internet functioned more like print than broadcast, thus giving wide latitude of protection to it. Now, 20 years later in Packingham v. North Carolina, the U.S. Supreme Court would again weigh in on the parameters of free speech protection on the internet and again would offer far-reaching, almost absolutist protection of speech. In this presentation, I argue that much as it did 20 years ago, the Court has again failed to assess the power of the internet in the United States by likening it to a public park and now has also ignored the global nature of the medium as well. Specifically, I will place my analysis of the Packingham ruling within the larger context of internet speech issues and will conclude that the Court went too far in its ruling, offering what seems to give unfettered power to social media outlooks such as Facebook and Twitter to determine what speech should be free and what can be restricted and when. This approach to internet speech runs counter to traditional democratic values, downplays the social harms caused by certain types of internet speech (such as hate speech, cyberbullying, revenge porn, etc.) and ignores recent political incidents (such as the election tampering through ad placement on Facebook).

Presenter

Chris Demaske - UWT/SIAS

\section{The institutional capacities as a ground of the Administrative State}

This research adopts Brazilian constitutional design as object, by specifying the main institutions that compose the Brazilian`s central dynamics: the powers of State in the federal dimension, the Presidency of Republic, the National Congress and the Constitutional Court. The main problem that involves the institutions in analysis is similar to the difficulties encountered in other constitutional designs: the crisis of the Madisonian model. Traditionally, Brazilian democratic reality is organized from a formal-normative constitutional basis. However, that is a limited comprehension about democratic phenomenon`s dimension and complexity. In fact, the constitutional performance of the Administrative State is consolidated from the performance and behavior of the basic institutions of society, beginning with its own powers. Discussing about institutional performance and behavior means to understand the phenomenon of institutional capacities, from its concept to its practical dimension. In this sense, the contributions from the theories of institutional designs, institutional dialogue, and deliberative democracy, among others are of central importance. 
Presenter

Carlos Bolonha - Universidade Federal do Rio de Janeiro

PresentingCo-Author

Maíra Almeida - Federal Universityof Rio de Janeiro

\section{The right to information in Brazil and The United States: a comparison by the decisions of the Supreme Courts}

The article makes a comparative analysis between the main judicial decisions of the The Supreme Court of the United States and the Brazilian Federal Supreme Court regarding the right to information. By comparing constitutional norms and the effectiveness of international conventions and legislation in their respective countries, it is sought to identify stare cases of both courts that are similar when weighting fundamental rights in which access to information is highlighted as the prevailing fundamental right. Focused on Comparative Constitutional Law, the author identifies coinciding arguments within the decisions that ratify the right to information as recognized in the international legal system and implemented at the national level, even though both countries originate in different legal systems. Divergent opinions in the decision-making content serve as an extension of the discussion on the limits established by each State to guarantee secret when they need it.

Presenter

Amanda da Fonseca de Oliveira - Universidade Federal Fluminense

\section{Session III}

This session focus is related to current trends in these regions relating to Corporate Law, Business and Trade . Examples might include discussions of contemporary political or legal challenges faced by governments, social groups or/and corporations and/or analyses of emerging trends in corporate law theory as they are related to Asia or the Americas.

Chair/Discussant: Fernanda Duarte - UNESA e INCT/InEAC/PROPPI/UFF

Managing the Risks of Corporate Fraud: the Evidence from Hong Kong And Singapore 
Since the Asian financial crisis of 1997, Hong Kong and Singapore have implemented reforms that promote independence and monitoring competency of the boards of directors of their listed companies. However, with the advent of the financial crisis of $2007 / 2008$, a wave of fraud cases prompts the question as to the effectiveness of these reforms. Analysing a sample of 62 listed companies which are discovered to be fraudulent between 2007-2014, and comparing against a matched sample of nonfraudulent firms, we find that the fraud companies tend to combine the roles of chairman and chief executive officer and have fewer non-accounting finance experts. Otherwise, there are no material differences in the other corporate governance characteristics. The reasons for the limited role of independent directors in preventing fraud are due to the low threat of enforcement actions and their incentives to side with controlling shareholders. Our results suggest that the high expectations of independent directors are only partially fulfilled.

Presenter

Wai Wan - Singapore Management University

Non-Presenting Co-Author(s)

Christopher Chen - Singapore Management University

Chongwu Xia - Xiamen University

Say Goo - Hong Kong University

\section{Qualification and Treatment of Stock Market Offences at the Intersection of Two Legal Frameworks}

Unlike crimes against a person or property handled by the police, stock market offences (market manipulation and insider trading) benefit from an uncertainty as to their legal treatment and their criminal status. This differential treatment translates into their legal categorisation (financial legislation), the responsible institution for their regulation (administrative regulator) and the variety of sanctions available (Lascoumes 1996). In Quebec, the "Autorité des marchés financiers" (AMF) is in charge of managing those stock market "illegalisms" (Foucault, 1975). The AMF's investigation practices reflect how some cases are prioritized over others in accordance with a series of determinants (situational, structural, or institutional). Based on a Foucaldian theoretical perspective and my ethnographic experience spawned by a year of participant observation within the AMF's investigative division, this paper aims to present concretely how AMF's actors manage cases of market abuse according to a game prioritization. Thus, it allows them to distinguish "bad" cases from "good" ones, and ultimately the "nice" offenders from the "spiteful" who must be prosecuted. Ultimately, this study shows that investigators intertwine two legal frameworks (penal and administrative) to modulate a 
privileged treatment that meets their needs by addressing the characteristics of the stock market "illegalism" and the AMF's internal institutional tensions.

Presenter

Marie Badrudin - Université de Montréal

\section{The Hybrid Logic of Executive Compensation of China's National Champions}

A hallmark feature of China's state capitalism is the central role of about 100 large, nonfinancial state-owned enterprises (SOEs) controlled by the State-Owned Assets Supervision and Administration Commission. They are often dubbed China's "national champions". Despite their importance to China's economy, the national champions' executive compensation system - an incentive mechanism commonly deemed important for modern organizational management -remains mysterious. This article traces the regulatory changes and more importantly explores pay data that were recently disclosed for the very first time by the central SOEs. It covers the pay information of over 900 SOE executives. The study shows a mixture of modern and traditional practices, commercial and non-commercial goals as well as market and government governance. It exposes political agenda and industrial policies undergirding the ostensibly financial evaluation criteria. It confirms the link between pay and performance, where performance is specifically defined by the state-owner's own terms. Moreover, it shows an uncertain relationship between performance and non-monetary incentives for SOE executives.

Presenter

Liwen Lin - University of British Columbia

\section{Intellectual Property in the Digital Age}

The current digital age brings challenges concerning technological innovation strategies development and execution to policy makers, legislators and companies of the most different industries. As Intellectual Property (IP) Legislation is not homogeneous over the world, it's up to each country the enforcement of IP by taking its own Office and the Trade-Related Aspects of Intellectual Property Rights (TRIPS Agreement) as a baseline. In this context, it's extremely strategic for companies managing the IP rights in an integrated way to appropriate their tacit knowledge and making the best use of their IP assets in order to explore the potentially profitable markets. Nowadays the energy sector is taking opportunities to improve quality and efficiency of its products and processes by using information and communication technologies with embedded softwares in the digitalization of its operational infrastructure. A case study of the electric power area encompassing the wind energy sector is presented. Data of patent applications examined in Brazil in the last 2 years were collected and analysed. Among the main findings, the 
study proposes an IP portfolio with patents, trademarks and know-how aiming the protection of inventions from competitors and increase of market share and profitability and shows the prevalence of few multinational companies and the absence of Brazilian companies, observing only public universities as national actors.

Presenter

Cesar Moreira - Universidade Estácio de Sá

PresentingCo-Author

Maria Ângela de Souza Fernandes - Academia de PI e Inovação - INPI

\section{The Elusive Meaning of "Fraud" in U.S. Federal Criminal Law: Mail Fraud and Securities Fraud}

Federal statutes and rules prohibit "fraud," but fail to define it. It has thus fallen to the courts to define the term. Anglo-American law has a long history of defining fraud broadly, but the Supreme Court has given the term a relatively narrow definition in its two most prominent contexts: securities fraud under Rule 10b-5 and mail/wire fraud under 18 U.S.C. $§ 1341 / 1343$. The Court has used entirely different interpretive methods and justifications to define "fraud" in each instance. In mail fraud, it has invoked (without much actual support) the supposed "common law meaning" of "fraud." In 10b5 , it has referred to the "commonly accepted meaning" of statutory language with no reference to the common law. Despite using these entirely different methods, the Court has somehow reached very similar conclusions-which I argue are wrong in both cases, for different reasons. This paper supports this argument with evidence from commonlaw history and Supreme Court precedent. The paper relates to the conference theme of "Law at the Crossroads" in that it explores the intersection of the common-law concept of fraud and its statutory definition, as well as the intersection of legislation/rulemaking on the one hand and judicial interpretation on the other.

Presenter

Thomas Joo - University of California, Davis, School of Law

\section{Toothless Leviathan? A research on anticompetitive control mechanisms of the Brazilian market}

The aim of the current article is to answer how Brazilian institutions respond to cartel and criminal practices related to market concentration acts in Brazil. The adopted methodology followed an ethnographic approach through direct observation and oneon-one interviews with professionals from organs involved in the investigation of illegal acts. The matter is relevant since anti-competitive attitudes in the market force consumers to decisions made by few privileged businessmen. I assume the hypothesis 
that the collaborative action of anticompetitive control institutions provides safety and transparency to the market. Among the legal repression instruments one finds the plea bargaining and leniency, which are investigation tools based on the trust of the investigated person in the institutions. However, there are nine institutions in Brazil that, somehow, want to impose their methods and use evidences to apply sanctions. The main argument advocated by them is that the outspread of control and punishment institutions creates uncertainty in people interested in helping the justice. Such uncertainty takes the applicant away and in hazardous to the market, to consumers and the economic development in the country.

Presenter

Wagner Brito - Universidade Estácio de Sá

\section{SessionIV}

Chair: Rafael Mario Iorio Filho - Universidade Estácio de Sá e INCT-InEAC

Discussant: Fernanda Duarte - Universidade Estácio de Sá e INCT-InEAC

Deference Measurement: An analysis of the degree of mutability of Administrative Review decisions in the Brazilian National Transit System, using the Judicial Review as a parameter.

The Brazilian National Transit System has administrative mechanisms and administrative instances, which aim to give applicability to the constitutional and legal guarantees to the individual in the transit issue. In Brazil, the judged administrative questions don't have immutability character, and it is possible, through the logic of you can always provoke the jurisdictional action to review the act of Executive Branch's. This review may have a broad spectrum of retification of the entire administrative procedure, and may reach the last administrative review of the application of a certain legal penalty, which creates a parameter to analyze the final product given by the Administrative Review, verifying the its degree of mutability by the possible later interference of the Judicial Review, as well as providing important behavioral information of the institutions of the National Transit System and the performance of its agents, as well as of the Judiciary's own role in correlating with the organs of the Executive Branch, which are in the exercise of their functions of a technical nature, observing how the Judiciary Power behaves in relation to the primary and revisionary action of the Administrative State in the thematic of the Traffic. The hypothesis raised is that, despite there being in Brazil an exponential behavior of judicial activism; statistically, the Judicial Branch ratifies the Executive acts, verifying a degree of immutability of administrative decisions.

Presenter 
Marcos Fernandes de Souza - Federal Universityof Rio de Janeiro

\section{Institucionaldesing of regulation in Brazilian energy sector: limits imposed on the regulation of a sector dominated by the natural monopoly}

Although there is an important doctrinal part that defends the model of natural monopolies as a regulatory standard of sectors considered as of public utility, the questioning about the freedom of initiative and competition, as drivers of a model of market dispute capable of offering better cost recipient of these services, is endowed with considerable strength. From this, the hypothesis that the regulation of these sectors, if dimensioned from other criteria, can be shown to be so much more beneficial when considering the ends for which it is intended, being they the public interest and the performance of the State in the direction of best possible model or achievable - second best. The central point of this research is to conflate paradigms that guide the natural monopoly argument as the exclusive regulatory model to be applied in sectors with a public utility political status vis-a-vis the concrete effects of regulation, impacts and satisfaction for the ends proposed. Therefore, this study will be based on the concrete institutional design of the agencies responsible for regulating this sector in view of its role in correcting market failures and results achieved. Finally, the methodology consists of bibliographical analysis and comparative law.

Presenter -

Gianne Lima - Federal Universityof Rio de Janeiro

PresentingCo-Author

Beatriz Oliveira - Federal Universityof Rio de Janeiro

\section{A comparative analysis of deference in the supreme court: The judicial review applied to Brazilian and Canadian regulatory agencies}

The creation of regulatory agencies had as main purpose the specialized regulation of economic sectors. From the technical legitimacy, the Agencies would be endowed with institutional capacity for the normative edition and application of sanctions within the regulated sector. However, once the judicial control of administrative acts has been enforced, the decisions of the agencies, even if technically sound, can be altered by courts - institutions with little or no technical legitimacy - which may make it difficult to achieve the finalities that led to the creation of the agency. The phenomenon of the judicialization - the main cause of the crisis of the Brazilian judiciary - fomented the discussion about the modulation of the judicial control of the acts of the public administration. With the objective of analyzing quantitatively the judicialization and judicial deference of decisions of federal regulatory agencies, it was made the survey of 
empirical data related to the interval between 1997 and 2017, from the platforms of the Supreme Brazilian and Canadian courts, as well as the bibliographic review .

Presenter

Gabriella de Sousa Rodrigues - Federal Universityof Rio de Janeiro

Presenting Co-Author

Gianne Lima - Federal University of Rio de Janeiro

\section{An alternative for the effectuation of human rights, in the light of regulatory agencies}

Within the perspective of creation of regulatory agencies, in Brazil is established a questioning about the concept of them, which makes the debate about the effectiveness and autonomy of these agencies of great importance. Therefore, the performance of these regulatory institutions, the subject of questions turns to the presence or not of essential elements that classify them as such. In light of this discussion, the difficulty of conceptualizing what regulatory agencies in the Brazilian institutional design is identified as a problem, therefore, the difficulty, also, of determining the level of autonomy of these institutions when defining economic policy and what they will seek by means of their regulation. Hence, it is necessary to analyze the elementary criteria of an agency. It is possible to build a hypothesis, where considering the model of regulatory agencies of the United States of America as a base to Brazilians model, it is necessary for the proper functioning of these institutions to define what characteristics are indispensable for their determination, thus guaranteeing criteria for that there is autonomy and regulation of fact by these agencies. The theoretical background of the work focuses on the analysis of state administrative Theory. In addition, the hypothetical-deductive criterion will be used as methodology. The time frame of the paper focuses on the period of institution of the regulatory agencies to the present day.

Presenter

Luiza Silva - Universidade Federal do Rio de Janeiro

The characteristics of the Civil Registration System in Brazil: its importance in the implementation of public policies.

In mass societies, individuals barely know each other, which is why it is necessary to have a public institution specially prepared for the purpose of verifying, inscribing and publicizing the acts and facts that relate to the identification of people, especially their legitimacy and civil capacity. In Brazil, this activity is developed by the Civil Registry of Natural Persons. Furthermore, in addition to the specific function of controlling the events of the natural person's state, the Brazilian Registraion also has the role of feeding 
the state databases with the vital information of the people so that governments can implement their policies. By law, Officials in charge of civil registration are obliged to inform public bodies about births, marriages, deaths and other events in the life of the individual, so that they can create social policy strategies. For example, birth reporting to census tracts indicates the country's population size (miliary effective) and birth conditions (with or without care). As for death, its news prevents the undue payment of social benefits, which generates savings for the public coffers. Thus, in poor countries, such as the Brazilian case, where government organizational structures are flawed, the Civil Registraion acts as the State's arm, insofar as it assists in capturing the vital data of the population, so that they can be thought and implemented by Brazilian rulers .

Presenter

Marcelo Tiziani- Independent researcher

\section{Policy Tug Of War: A Socio-Legal Inquiry About Access To Health Via Litigation In Brazil}

This paper aims to analyse, from the result of a qualitative analysis of healthcare litigation and judicial decisions in Brazil, the role of courts in shaping public policy in healthcare, and how the enforcement of second generation rights discourse can be a tool for judicial empowerment, creating an institutional tension among powers. Litigation involving the healthcare system in Brazil has become a topic of academic interest due to the vast number of individual legal actions filed in the last decade requesting drugs and medical devices not covered by the system. The phenomenon has not only exponentially increased in numbers, but is believed to have created a significant distortion in the country's policy. The Brazilian judiciary has ruled on over 300,000 cases of individual litigation against the State. Decisions are usually reasoned around the interpretation that the Brazilian constitution promises universal health to every citizen (article \#196), and that such promise assures to the individual the right to access drugs and treatments not covered by the healthcare policy established by the Executive. However, what the interviews show is that the socio-legal motivation is not always aligned with the legal reasoning, pointing out to a true 'policy tug of war' among powers and an institutional trust crisis in the country, which has created islands of powers, isolated and selfempowered.

Presenter

Fernanda Farina - University of Oxford

\section{Citizenship, Minorities and Human Rights: comparative perspectives in American and Asian Societies}


This session covers legal and social issues related to the human rights debate, including discussions of contemporary political or legal challenges faced by minorities considered as social groups or individuals related in Asia or/and the Americas.

Chair:Ana Luiza da Gama e Souza - Universidade Estácio de Sá /Brazil

Discussant:LaraGoés- Brazilian War School (ESG)/Brazil

\section{Dangerous Positions: Male Homosexuality in the New Penal Code of Iran}

What does it matter who has what position in the same-sex sexual act? The difference can be life and death. This paper examines the new penal code of Iran (2013) with respect to same-sex sexual acts among men, analyzing it in terms of its literal and symbolic significance for homosexual men in Iran and its broader meaning and function within the current socio-political and economic situation of Iran. What struck us in the new penal code is the distinction it makes between male same-sex partners in terms of their respective position during intercourse. In a somewhat counter-intuitive manner, the penetrating man receives more leniency than the one who is penetrated. We argue that this new provision in the law can be interpreted in several ways. On the surface, it is a move towards greater leniency towards a whole class of gay men. Beneath the surface, the new provision reveals anxieties occasioned by the current crisis of masculinity in Iran as the country grapples with significant internal and geopolitical challenges. Further, we notice that, for the first time, homosexuality as a sexual orientation, rather than mere sexual acts, is explicitly named in the law, at once recognized and punished.

Presenter

Aryan Karimi - University of Alberta

\section{Comparative Legal Study on Indigenous People's Right to Land and Natural Resources}

Before the UNDRIP was adopted by the General Assembly, one of the very few nonUN members, Taiwan, had promulgated the "Indigenous Peoples Basic Act" in 2005. However, recent developments of the Indigenous Peoples Basic Act in Taiwan deepened, rather than relieved, the tension between indigenous people and the government. The delimitation of indigenous land case and the case of mining right extension explained the difficulties of defining the nature and content of indigenous people's right to land and natural resources. This project will study on the following topics. First, I argue that indigenous people's right to their land or natural resources is not the same with traditional property rights. Rather, it is also a matter of indigenous 
sovereignty. Secondly, the relationship between "consult," "consent," and "participation" will be further investigated. I will bring some perspective of the nature of indigenous rights to their land and natural resources through studying cases decided by Inter-American Court and Commission, such as the 2002 case of the Western Shoshone Dann sisters, the 2004 case of Maya Indigenous Communities of the Toledo District, the 2006 case of Moiwana, the 2007 case of Saramaka, and the 2012 case of Kichwa Indigenous People of Sarayaku. Through doing comparative research between Taiwan and Inter-American Court and Commissions, I believe the nature and content of indigenous people's right to their land and natural resources will be further clarified.

Presenter

Yu-Yin Tu - Tamkang University

\section{Misgendering Trans People in the Canadian Legal System}

This paper analyzes written decisions of Canadian judges and administrative decision makers to determine whether they refer to trans people by their preferred name or pronoun. To this author's knowledge, this is the first empirical analysis of this type. There have been several papers which have used case studies to examine this problem, including McGill and Kirkup's 2013 paper "Locating the Trans Legal Subject in Canadian Law: XY v Ontario". However, there has been no complete survey of how judges gender trans people. The author performed a search in LexisNexis using the term "transgender OR transsexual", and coded whether the judge or administrative decision maker used the preferred name or pronoun. The search generated 459 results. In the majority of results, the name or pronoun of the person was not applicable, primarily because the decision made reference to a policy using the word "transgender". Of the relevant decisions, at the federal level $4 \%$ of decisions misgendered the trans person, while at the provincial level $13 \%$ of decisions misgendered the trans person. This data is examined in the context of other empirical studies, primarily the Trans PULSE Survey, to determine the effect of this misgendering on trans people in the legal system. The paper concludes with an analysis of policies and statutes relevant to misgendering in court, and concludes that despite the seriousness of the problem, there is no policy that adequately governs this issue.

Presenter

David Isaac - University of Western Ontario

\section{Critiquing the use of criminal law to protect women's rights in Mexico}

Since the 1990's, many reforms have been made to the criminal justice system in Mexico to protect "women's rights". Reforms were undertaken to transform old crimes to reflect "new values". This is the case with rape, sexual abuse, and murder. New 
crimes were also introduced into the law. This is the case of femicide, discrimination, sexual harassment, failure to pay child and spousal support, obstetric violence, crimes against reproductive rights, trafficking, risk of infection, and family violence, which are all punishable with time in prison. This paper is focused on providing an assessment of this use of criminal law. Does criminal law, as it has been enacted, actually tackle "the problem" of gender discrimination and violence that violate women's rights? Does it actually punish these crimes? Does it contribute to their prevention? My assessment, however, is not only limited to evaluating whether or not these reforms have fulfilled their own objectives. Law generally operates beyond its makers' intent, in ways that are not always imagined, nor, of course, desired. What have been the effects of this use of criminal law, beyond what their enactors hoped to achieve? What have been the unintended consequences of this "turn to criminalization" as a strategy to protect women's rights? Has it produced harms that were unpredicted? If so, what have they been?

Presenter

Estefanía Vela Barba - Yale Law School

\section{Gender and Constitutions: A Cross-national Analysis of the Impact of Gender Provisions on Women's Equality}

Feminist institutionalism is concerned with how institutions create, recreate, or challenge gendered power asymmetries (Krook and Mackay 2011; Chappell and Waylen 2013). Much of this literature focuses on the effects of gender quotas, women's policy agencies, and federalism. The effect of constitutional gender provisions has received less attention, especially empirically. Constitutions vary tremendously in how they treat gender difference and women's rights. We examine how sex and gender difference is recognized in national constitutions in roughly 100 countries. We systematically code any constitutional provisions that mention sex, gender, motherhood, or family. This allows us to construct a typology of constitutions grounded in feminist theory as well as an index of egalitarian provisions. The statistical analysis uses both of these measures to test the relationship between the constitutional recognition of gender difference and scores on cross-national indicators of women's political, economic and social status. Drawing on the literature on women's rights and equality, we also include variables for women's representation, political institutions, political culture, as well as variables that control for economic development and the rule of law. We hypothesize that egalitarian constitutional provisions will be associated with higher scores on measures of women's equality.

Presenter

Priscilla Lambert - Western Michigan University

Presenting Co-Author

Revista Juris Poiesis - Rio de Janeiro. Vol.21-n²6, 2018, pg.304- 368. ISSN 2448-0517 Rio de Janeiro, 30 de agosto de 2018. 
Druscilla Scribner - University of Wisconsin Oshkosh

\section{One Step Closer to the Perpetrator: Can Canada's Resettlement of Syrian Refugees Model provide a Spring Board for Launching Effective Investigations into the Alleged Commission of Core International Crimes?}

The exercise of universal jurisdiction by sovereign states and their national courts over the core international crimes (war crimes, genocide and crimes against humanity) provides one of the most promising legal tools for fighting against the impunity of those responsible for their commission. This is especially the case when there is little chance that a given post-conflict society will undertake domestic legal trials of the alleged perpetrators of these crimes in good faith, or that the case would be referred to the International Criminal Court or to a hybrid court. A good case in point is Syria and its civil war raging since 2011. In this regard, Canada's Crimes against Humanity \& War Crimes Act has been praised for providing the criminal legal system with teeth to investigate and prosecute the alleged commission of any of these crimes by individuals claiming refugee status. The article examines whether Canada's extensive resettlement of Syrian refugees through private and public sponsorship channels has the potential of contributing credible information towards a database of cases that could warrant effective domestic investigations and prosecutions of criminal responsibility in the near future. In addition to examining the challenges and prospects, interviews with Syrian refugees would gauge their views as to the extent to which this would be a desirable development that would bring them one step closer to accountability for serious violations of international law.

Presenter

Rouba Al-Salem - Center for Human Rights and Legal Pluralism, Faculty of Law McGill Univeristy

\section{Human Rights in Asia and the Americas}

This session covers legal and social issues in Asia and the Americas related to the human rights debate. Examples might include discussions of contemporary political or legal challenges faced by governments, social groups or individuals, analyses of emerging trends in legal theory as they are related to human rights in Asia or the Americas, and/or projects that concentrate on particular legal or social problems related to human rights and endemic to societies in either region.

\section{Session I}


For this session, papers dealing with issues of sexual orientation, family models, child's protection and gender are particularly encouraged.

Chair/discussant: Edna Raquel Hogemann - UNESA

\section{The Contractual Construction of Polyamory}

Polyamory denotes aspirationally gender-egalitarian, consensual non-monogamy. How do polyamorists understand their relationships, when it seems that monogamous relationship categories do not apply? I find, in both polyamory-community materials and in academic work, that a metaphor polyamorists often choose is contract. In this frame, a relationship is a set of obligations that people agree to up front, occasionally modified by mutual consent. I bring the contract-status debate in family law to bear. Some scholars have seen contract as an egalitarian alternative to older status-based understandings of the relationship between husband and wife. Others are sceptical, arguing that contract naturalizes the exercise of power, is blind to relevant categories like gender, and cannot compass the way relationships evolve over time. Some problems identified with contractual ordering in intimate relationships are exacerbated by the polyamorous context. A frame that puts its emphasis on up-front individual decision-making is even less felicitous for relationships that can involve shifting groups of more than two people and the power dynamics this entails. On the other hand, polyamorists are fully aware of these issues and have developed contractual strategies to defuse them. I close by asking whether we can already see within polyamorous practice a way for intimate relationships to reject both status-based oppressions and the problematic aspects of contract.

Presenter

John Enman-Beech - University of Toronto

\section{Recognizing the legal value of affection as a fundamental human right}

It focuses affection as an ontological and juridical value, intrinsic to the human personality. It recognizes the derived concept derived from it, under a truly inclusive normative sign, through its insertion in the role of human rights, in the terms of toleration as worked by Walzer, representing egalitarianism and pluralism, giving centrality to the concept of equality to open a possibility of reflection on the right to affection as a guarantee of being and dignity. It discusses the concept, based on the jurisprudential analysis of judgments, under technical and legal bases that the Judiciary, through the Superior Courts, has been used in the recognition and protection of the most diverse family entities, based on the legal value of affection, through the systematic interpretation of the legal system, since freedom and equality constitute constitutional principles, which constitute rules of full effectiveness. It lays the foundation for a hermeneutics of interpretation according to the Constitution, without losing sight of the subjective character of the affective value possessed, taking into account that the affection value is allowed to travel, both by the Fundamental Rights Theory, to have a constitutional feature, as by the Theory of Personality Rights, because it is effective subjective right independent of the discussion between public and private.

Presenter

Thiago Souza - UNESA

"Family constellation": solving family conflicts in several aspects in brazil and canada 
There is a limit to state intervention in the family sphere, considering that the state interferes to provide the necessary and special protection in the Federal Constitution of Brazil. Considering that without intervention in the strict sphere of the members of each family, some choices as conjugal coexistence, how to dispose of the couple's goods, free acquisition and administration of real state property, family planning in how to deal with children. The Brazilian's Constitution guarantees the role of the State as the protector of families, than it becomes importante to create alternative ways of solving conflicts. Several advances have taken place, promoting the adaptation of the Right to the diverse social demands in the family sphere as the recognition of common law marriage, extended to the same sex ones. Also the civil registry of marriage, assisted human reproduction, adoption, civil registry of birth in equality of conditions, multiparentality, affective abandonment, shared custody, parental alienation etc. The purpose of this paper is to analyse the limits of people's private autonomy avoiding family legal disputes, suggesting a peaceful solution, as "family constellation", a therapeutic technique to reestablish and harmonize a better structure of life in the brazilian's and canadian's society.

Presenter

Ana Cristina Augusto Pinheiro - Universidade Estácio de Sá

\section{Instrument Choice in Family Law: The Spousal Support Advisory Guidelines}

The Spousal Support Advisory Guidelines guide the determination of spousal support (alimony) following the breakdown of a marriage or marriage-like relationship, by structuring the broad grant of judicial discretion contained in the relevant legislation. While they do not in theory bind decision-makers, appellate courts across Canada have embraced them; some have gone as far as requiring trial judges to justify departing from them, essentially incorporating them into law. If official acceptance is a measure of success, the Advisory Guidelines are an extraordinary feat. They are also unique; while administrative authorities use similar non-binding instruments, there is little history, in Canada, of voluntary judicial deference toward instruments that curtail discretion. This raises important questions: Why did the legislator choose non-binding guidelines, rather than mandatory rules, as in the case of child support? What explains their success? Scholarship on the Advisory Guidelines is scant. This paper, by examining their success from the perspectives of instrument choice and regulatory theory, fills that gap. It expands the reach of instrument choice theory, from economic regulation, to social and family policy and to questions of economic equality, and contains lessons for other domains affected by the difficulties associated with the broad exercise of judicial discretion.

Presenter

Jodi Lazare - Schulich School of Law, Dalhousie University

\section{Reconsidering the Interplay of Money and Adoption: Open "Kinship" Adoption as a New Paradigm}

While commercial surrogacy continues to function both domestically and internationally, commercial adoption, at least explicitly, is vigorously condemned as unlawful baby-selling. Domestic laws prohibit compensation beyond expenses to birth mothers and fears of fraudulent compensation to birth families have shut down transnational adoption from several countries. Yet, historically adoption has always involved money in changing but vital ways. Financial remuneration to birth parents may not be unethical when other intermediaries are receiving 
payments. Compensation to birth parents may be necessary to facilitate adoption when a country's social welfare institutions are not able to remove children from families where there is abandonment or neglect due to extreme poverty. In this article, I suggest that ethical commercial adoption could occur by either altering the way we perceive adoption or the nature of the compensation keeping in mind the changing nature of family formation and modern perspectives on children's rights. First, remuneration to birth families could be made less problematic by regulatory frameworks that ease the fear that babies are being sold due to undue financial pressure. Second, I argue that open adoption, where birth parents do not disappear or sign away all rights to the child, can make financial remuneration look more like an act of charity and less like an act of acquiring a child in a proprietary way for one's own benefit.

Presenter

Pamela Laufer-Ukeles - Academic Center of Law \& Science

\section{The right of marriage for women with disabilities in the Haredi society}

My research deals with the implementation of the right of women with disabilities in Haredi society to marry, and focuses on the normative aspects of the practicallity of this right. The integration of marriage of couples with disabilities in Haredi society is a fascinating meeting point of a normative system of state, religion and community. State law creates a platform for such marriages, whether by establishing and financing housing systems for couples with disabilities, or by regulating and supervising professionals of various professions who are key actors in this arena. According to religious law, a candidate for a marriage defined as a "fool" may not marry. In general, the rabbi will encourage marriage only when the candidates are able to observe the laws of family purity. Community norms also influence the design of these marriages. Marriage at a young age in the Haredi community shape the dreams and aspirations of people with disabilities to equality and normative integration.

Presenter

Chaya Gershuni - Tel Aviv University

\section{Session II}

Papers dealing with issues of immigration and refuge are particularly encouragedfor this session.

Chair: Ronaldo Lucas da Silva - Universidade Estácio de Sá

Discussant: Rafael Mario Iorio Filho - Universidade Estácio de Sá e INCT-InEAC

Notes on the juridical protection of Venezuelan migrants in Brazil: searching for alternatives to migratory policies

In today's world, the issue of forced migration, although not a new one, is a serious problem for a number of States and for the very people who participate in such flows, who are often deprived of the exercise of rights and assimilation in the political community of the Receiving 
State. The present study aims to analyze the legal aspects of the migration of Venezuelans in Brazil, after the crisis intensified in the country, thus having a temporal cut after 2013. Although the 1951 Convention has inaugurated a phase in the construction of international legal protection for refugees, it does not provide answers to current problems that lead individuals to flee their countries, such as generalized violence, and the total lack of conditions for States to provide dignity to its people. This is the case of Venezuelans, who migrated to Brazil in the face of the humanitarian crisis that crosses the country. Following the traditional legal definition of the Convention, the National Committee for Refugees in Brazil (CONARE) didn't recognize Venezuelans who entered Brazil after 2013 as refugees, a position that is not in line with the brazilian law which extended the refugee definition to individuals who flee their countries because of serious human rights violations. From the case of the Venezuelans, it seeks to extend legal protection to those who migrate as a result of the situations mentioned, through the new approach of juridical instruments as well as as Brazilian policies.

Presenter

Ana Paula Teixeira Delgado - Universidade Estácio de Sá

\section{Immigration Detention and the Problem of Time: Lessons from Solitary Confinement}

Canada is currently reforming its immigration detention regime, in an effort to create more just and humane detention conditions. In this paper, we examine this effort focusing on what we believe to the core problem with detention, which we refer to as the problem of time. We argue that absent legislative reform to impose clear time limits on detention - and the external oversight to ensure these limits are respected - this overhaul will likely entrench the very problems it intends to resolve. The law on detention will remain inconsistent, and detention will continue to devastate and dehumanize those in its care. We develop this argument by analyzing Canada's detention regime against the law and practice of solitary confinement. There are lessons to be learned from the mistakes made by government throughout the long and ineffective history of solitary confinement reform. This paper is our attempt to draw out those lessons.

Presenter

Efrat Arbel - University of British Columbia Allard School of Law

Presenting Co-Author

Ian Davis - University of British Columbia, Allard School of Law

\section{Encounters in the Middle of Nowhere: Migrant Detention and Migratory Legal Aid in Texas}

The rural town of Dilley, Texas sits at a unique sort of crossroads, one with which only a select few are acquainted. It's the home of a so-called family detention center known as the South Texas Family Residential Center. This exceptional migrant detention facility, which detains only asylum-seeking mothers and minor children, serves as a sort of initial asylum claim processing facility, wherein these detainees are interviewed by asylum officers who then determine both their personal credibility as well as their potential for pursuing a claim in the U.S. People detained here come from and travel through points across the globe, mothers and children meeting one another in the center in this quiet border town. Yet Dilley attracts another 
migratory group, one made up of lawyers and legal assistants. These aid workers arrive each week from places across the U.S. to provide pro bono legal assistance to these detainees, including helping them understand these legal processes and preparing them for interviews. Most of these volunteers stay for only a week before returning to their homes. This paper examines what daily legal practice looks like at this literal and conceptual crossroads, and, perhaps more importantly, how legal practice feels at such a site. Analyzing the ethnographic data I've collected over the last year, which has been a pivotal year for legal activism and asylum law, this paper explores such ideas through the voices and experiences of these legal aid volunteers.

Presenter

Erin Routon - Cornell University

\section{An Organizational Framing Approach to the Study of Immigration Laws and Policies in a Presidentially Centric Governmental Structure}

Outside liberal democracies, how is immigration law formulated? In a presidentially-centric governmental structure, the president retains the most significant power. The politics of immigration literature, however, lacks a theory about how the lawmaking process occurs in such a context (Hampshire 2013; Hollifield, Martin and Orrenius 2014). This is a timely question, considering the growing power that chief executives are claiming for themselves worldwide. In this project, I address the role that high and mid-level government administrative officials play in the discussion and formulation of laws inside the executive but below the level of the president. Specifically, I explored how differently ranked governmental officials made sense of and negotiated the terms of immigration law in a context characterized by conflicting interests, information gaps, and organizational constraints. I found that positionality within the Chilean executive hierarchy shaped how individuals and groups framed the government's role in managing immigration law. This paper builds on an in-depth, ethnographic case study of immigration policies in Chile developed between 2014 and 2016 during which I spent twelve months acting as an active policy advisor to the Head of the Department of Immigration.

Presenter

Mayra Feddersen - University of California, Berkeley

\section{The Resolution 2272 (2016) from the security council and the United Nations positioning against sexual abuse and exploitation by their peacekeeping forces}

Among the many accusations already made against UN peacekeepers over the years, which include homicides and torture, the most recurrent, and which presents itself as the object of this research, is that of sexual abuse and exploitation against women and girls. Expressing its deep concern at the serious and continuing accusations against UN peacekeeping operations, the Security Council approved Resolution 2272 (2016) on March 11, 2016. The present paper, based on bibliographical and documentary research, aims to: present the legal basis for the protection of Human Rights by the UN peacekeeping forces; demonstrate the persistence of crimes of sexual abuse and exploitation by members of the peacekeeping force; and to review UN Security Council Resolution 2272 (2016) and the UN's "Zero Tolerance" policy, based on official reports and announcements issued within the framework of the United Nations. It is concluded that, after being without action on such crimes for more than a decade, the UN has 
taken an important initiative through the Resolution in question, in order to ensure the image of the organization, punish those responsible and protect the possible victims of such crimes.

Presenter

Sarah Dayanna Lima - Centro Universitário Estácio do Ceará

\section{Constitucional Law and Human Rights in Asia and the Americas}

Chair:Rafael Mario Iorio Filho

Universidade Estácio de Sá e INCT-InEAC

Discussant:Edna Raquel Hogemann- UNESA

This session examines legal development, constitutional law and human rights protection from the perspectives of both legal anthropology/sociology and comparative law in Asia and in the Americas. In particular, this session seeks to understand how political and historical paths, as well as global influences such as the universalization of human rights and democratic constitutional values, have shaped the formation and evolution of constitutional law and human rights protection in countries in Asia and the Americas.

\section{Paradigm Shift: Palestinian Human Rights in Israel's Highest Court}

This paper introduces a new framework for analyzing decisions of the Supreme Court of Israel in cases that involve state-sanctioned violence, Palestinian human rights (PHR), and international law. It contends that in its decisions the Court narrates a language of legality designed to veil the illegality of its rulings and the Court's own role in perpetuating PHR violations. The paper proposes a new four-part rhetorical paradigm under which the Court's decisions can be better understood, and uses major PHR cases to demonstrate the paradigm's validity and explanatory power. These cases involve the torture of Palestinian detainees, force-feeding of Palestinian prisoners, and starvation of besieged Palestinian civilians. The paper argues that the Court's rulings serve to legitimize-both internationally and domestically-the PHR violations that the state commits by equating Palestinian resistance to Israeli rule with global terrorism, and by creating a narrative that portrays Israel as a state that is in compliance with international law and custom. The paper contributes to our understanding of the role of the Supreme Court in the Israeli-Palestinian conflict and the Palestinian reality the Court's rulings shape. More broadly, it sheds light on how violence can be institutionalized and historicized by the judiciary of a state.

Presenter 
Michael Samuel - Emory University

\section{The Case of Women Driving: Bridging the Gap Between Social Progress \& Legal Reform in Saudi Arabia}

Effective in July of 2018, women in Saudi Arabia will be legally permitted to drive. Just prior to the announcement of this royal decree in October of 2017, Saudi officials held the position that 'Saudi society was not ready for women to drive'. This narrative has long been utilized as a justification for abstaining from implementing a plethora of human rights reformations. This research, which has been conducted in Saudi Arabia since 2014, draws upon hundreds of interviews and surveys of Saudi citizens to inquire on what sort of legal system Saudis themselves would create if given the opportunity. The results thus far reveal a society that is not only ready for legal reform, but has actually progressed far beyond the legal system that they currently live under. Beyond the case of women driving (of which 94\% of respondents supported); 74\% want freedom of religion, $82 \%$ want freedom of speech, and $85 \%$ wanted to end gender segregation in the country. The case of women driving thus serves as an informative backdrop into the realities on the ground of Saudi legal policy. The detailed results of the ethnographic research and how that translates into the future of Saudi Arabia's legal system will be discussed.

Presenter

Bethany Alhaidari- NUIG - Irish Centre for Human Rights

\section{Down with whores': Jack the Ripper's canonical victims}

Since the time of the Whitechapel murders in 1888, the case of Jack the Ripper has attracted great interest. Most of the attention has been directed towards the question of who Jack the Ripper was and the fears the anonymity of the murderer created. Less attention has been directed towards how the fears over and speculations about the case relate to who his victims were. The five victims which are the established 'canonical' ones earned at least some of their income from prostitution, and this was central to how the case was presented at the time, not least since one of the many letters received by the police supposedly penned by the Ripper, stated that "I am down on whores and I shant quit ripping them till I do get buckled". In this presentation we will explore depictions and descriptions of the (supposed) murder victims of Jack the Ripper. We are not preoccupied with the Ripper 'himself' but representations of those who symbolically gave birth to the legend, the 'whores' he appear to have predated on. The material will be depictions and descriptions of them and we will look at how they are represented in examples from various mediums (drawings, paintings, theatre, musicals, museums, penny dreadfulls, novels, film, TV-series and comics) from the 1880s until the present. 
Our starting assumption is that these representations express norms about femininity at different times, but also how prostitution represents broader social concerns. Coauthor:

Presenter

Per Ystehede/May-Len Skilbrei - University of Oslo

\section{Human rights, normative overlap and violence in the Brazilian western Amazon}

Human rights violations in the western Brazilian Amazon have increased considerably over the past ten years. The scenario is more serious on issues such as land conflicts. Indigenous people, people from quilombos, small peasants, traditional peoples and many other groups survive in the Amazon in a relation of deep identity with the territory and very specific forms of culture. Land disputes, transformations imposed by large economic enterprises and political interests threaten the survival of these vulnerable groups. My research studies how contemporary theories of justice underpin the possibility of applying human rights norms to resolve such conflicts. The partial conclusions demonstrate that in places where conflicts are most severe and cultural divisions deeper the application of these theories, preoccupied with the abstract universality of human rights norms, rather than helping may jeopardize the very survival of the threatened groups - which requires a reconstruction of our understanding of the local applicability of global human rights standards.

Presenter

Rodolfo Jacarandá - Federal Universityof Rondônia - Brazil

\section{Society's Constitutions: Studying Non-State Constitutionalization as an Element of Theory of Society}

The idea of societal constitutionalism has been proposed to describe processes of professional self-regulation within "collegial formations" (Sciulli). However, societal constitutionalism as adopted and elaborated within the social systems theory (Teubner) represents an extension of both - theory of constitutionalism and theory of society. Although the research within the framework of "Theory of Society" (Gesellschaftstheorie) has been marginalized after the domination of middle-range theories and micro perspectives, practical importance and unavoidable necessity of global societal theorizing has been proven by such global processes as extension of certain functional rationalities over the rest of societal communications. If certain system equipped by violent symbiotic mechanisms manages to extend itself over its own boundaries and breaks the operational closure of other functional areas, this causes nothing else but dedifferentiation and devolution of certain regional developments. The facts of partial differentiation are empirically observable in different regions of peripheral modernity as subordination of various functional spheres by religious 
fundamentalism, monetary speculations or military complex. It will be argued in the paper that an attempt to revive the forgotten perspective of an encompassing theory of society might be helpful to understand constitutional and legal reality of world society being transformed through processes of globalization and fragmentation.

Presenter

LashaBregvadze- Javakhishvili Tbilisi State University

\section{Access to Justice in Asia and the Americas}

Considering the geographical boundaries of the CRN1, this session covers challenges to access to justice, considered broadly as the access that citizens have to dispute resolution systems including but not limited to courts, but also to civil and administrative processes that might impact on protecting rights. Papers might include discussions on access to justice on its two dimensions: procedural access and also substantive justice. Examples dealing with issues of effective access to justice, reductions in costs, legal aid services, access to lawyers and access to courts and the efficaciousness of a justice system in meeting the dispute resolution needs of its citizens are welcome.

\section{Session I}

\section{Chair: Flavia Lima- UNICAP}

\section{Discussant:Bruno Rezende - UNESA}

Considering the geographical boundaries of the CRN1, this session covers challenges to access to justice, considered broadly as the access that citizens have to dispute resolution systems including but not limited to courts, but also to civil and administrative processes that might impact on protecting rights. Papers might include discussions on access to justice on its two dimensions: procedural access and also substantive justice. Examples dealing with issues of effective access to justice, reductions in costs, legal aid services, access to lawyers and access to courts and the efficaciousness of a justice system in meeting the dispute resolution needs of its citizens are welcome.

\section{The Right to Counsel in Housing Court: A Moral, Social, and Economic Imperative}

Each year, nearly three million Americans are evicted from their homes. With no right to counsel in housing court, nine in ten tenants enter the courtroom alone. The fallout that results from this power imbalance is devastating: housing insecurity creates financial instability and a range of adverse social consequences. Neighborhoods with high eviction rates see falling property values, higher unemployment, and require more social services. Access to counsel in eviction proceedings curbs these ill effects: $96 \%$ of tenants with legal representation remain in their homes. Eager to enact sound social and 
economic policy, some large cities across the country offer free legal services for lowincome people facing eviction. For example, New York City has implemented a plan to spend \$155 million per year providing attorneys to low-income defendants in housing court. Conservative estimates show this investment in eviction prevention would allow New York to forego $\$ 750$ million in annual homeless-assistance spending. However, disadvantaged jurisdictions cannot afford to taper homeless services and simultaneously endow eviction prevention programs. Pro bono solutions and targeted federal funding, memorialized by federal legislation, are necessary to keep all Americans in their homes. As communities across the United States strive to improve access to stable, decent, and affordable housing, policymakers must work to help residents to remain in the homes they have.

\section{Presenter}

Jared Fink - Temple University Beasley School of Law

\section{The Guarantee of Access to Justice for the Poor and Vulnerable in Brazil}

This paper aims to describe the access in justice in Brazil, focusing on de Public Defender's Office in the State of Rio de Janeiro, noting that Brazil and United States have different mechanisms for access to justice for poor people.. The Brazilian Constitution of 1988 represented a real milestone for the implementation of Democratic Rule of Law in the country, with the objective of the social inclusion of the majority of the population, giving mechanisms to make them effectively achievable. Rights that safeguard access to justice have been indispensable elements for a dignified human life. In order to try to guarantee equalization of access to justice, the Brazilian legal system have two important instruments: exemption of Courts fees and frees legal aid, that is considered, a fundamental right. To enable legal aid to those in need, to assist poor, lower middle-class or the vulnerable people in both civil and criminal matters, the "DefensoriaPública", was created. The objective of the present work is to demonstrate how the access to the Public Defender's Office of Rio de Janeiro is done in practice, the positive points and the obstacles encountered by the needy population, who need free justice, to have effective access to justice.

Presenter

Giselle Beran Medella D Almeida - Universidade Estácio de Sá

Access to Justice of the Poor in Brazil: Can we Hope in the Protagonism of the Supreme Brazilian Court?

The aim of this study is to highlight the lack of access to justice in the Brazilian prison. The Public Defender's Office in Brazil is not properly structured to meet ordinary demands, and it is even more difficult to provide the service to the incarcerated, which requires the solicitor's action for requirements such as regime progression and conditional release. As if the situation of the Brazilian prison system was not enough structured, there is a real shortage of state-sponsored legal assistance, resulting in overcrowding in the Prison Institutes, with provisional prisoners still without definitive condemnation or even without the rights provided for in the Constitution and in the 
criminal enforcement law. The Supreme Court allowed itself to evolve, albeit in a countermajoritarian way, in the interpretation of the Constitution, detecting the unconstitutional state of affairs, assuming on behalf of the Executive, the coordination and direction of the public policies related to the subject, preventing, for example, the contigency of funds already approved in the budget law. The purpose of the debate is precisely to verify the effectiveness of this stance by the Supreme Court, making the prisoner's access to justice more equitable.

Presenter

Ruy Walter Junior - Defensoria Pública do Rio de Janeiro

\section{Access to justice in the sphere of Labor Courts in Brazil - free legal services benefits}

The Brazilian judicial system has a specialized area for the demands arising from labor relations, at the federal level, with courts spread throughout the country and linked to Labor Federal Courts. The system is also composed by a Supreme Labor Court, named in Portuguese Tribunal Superior do Trabalho. To secure broad access to justice, ensured by the Brazilian Constitution, labor legislation contains its own rules guaranteeing free legal benefits to all workers who are unable to afford procedural expenses. In a legislation recently approved (Act N 13.467/2017), effective as of November 2017, the rules pertaining to free justice have changed, involving criteria and form of concession, as well as the scope of these benefits. The objective is to address the repercussions of this legislative change in the scope of access to justice in the labor sphere, a theme affection for the NEDCPD research group, maintained by the Master in Law Program at the UniversidadeEstácio de Sá, in Rio de Janeiro - Brazil and inherent to the CRN-01 proposal.

Presenter

Elaine Oliveira - Universidade Estácio de Sá

\section{Session II}

Chair/Discussant: Fernanda Duarte - UNESA e INCT/InEAC/PROPPI/UFF

\section{School mediation as a form of facing and preventing conflicts between children and teenagers}

It analyzes alternative means of conflict resolution in the educational institutions' environment, as a way of facing with the phenomenon known as bullying in the school environment. In addition, the research turns to an analysis of the mechanisms of conflict prevention, through the adoption of a methodology of dialectical-descriptive bias. It considers bullying as a problem of global dimensions, in democratic societies, which entails serious consequences. The research reveals the process of intersubjective mediation as privileged to ensure freedom and respect for 
the other, not only the simple imposition of authority, in the old molds of authoritarianism, based only on a struggle for power. The severity and extent of the problem and its consequences, in terms of respect for human dignity and the relevance of access and permanence in educational establishments, as a form of socio-cultural development, are referential elements to address the problem. To analyze the problem of social and cultural violence in the school environment, in a historical-cultural and juridical perspective, to discuss violence in the school space, based on Sociology, Education, Psychology and Constitutional Law, as well as the Statute of Children and Adolescents, as well as examining and proposing preventive measures against violence in the school environment, with emphasis on mediation initiatives and other alternative means of conflict resolution, is a contribution to the legal debate in the world.

Presenter

Claudia Fleischhauer - Universidade Estácio de Sá

Non-PresentingCo-Author

Juliana Araujo - Universidade Estácio de Sá

\section{Restorative justice as an instrument of a citizens 'legal practice}

It reveals restorative justice as a new model of conflict resolution in democratic societies, whose implementation does not imply the suppression of the traditional justice model, but which means a new paradigm of criminal justice, with a less punitive character, stimulating a citizen legal practice. It critically presents a penal system in which victim and defendant, who cease to be persons to become mere characters in narratives made by third parties. In this sense, the emergence of a new paradigm of Criminal Justice with a restorative profile, seeks to soften the fragility of this current system and rectify its failures. This new understanding of Justice, based on the culture of peace, gives voice and opportunity to all. Thus, different points of view are presented, the needs accepted and the responsibilities assumed, seeking to correct the mistakes and that each one is responsible for the construction of new paths with harmony and peace. The author considers that the real change brought about by Restorative Justice is to slow down the punitive and restorative character. The text concludes that Restorative Justice promotes active accountability of those who contributed directly or indirectly to the occurrence of the harmful event and the empowerment of the whole community, highlighting the need to repair the damage and recomposition of the social fabric broken by the conflict and its implications in the future.

Presenter

Ana Claudia Pinheiro - Universidade Estácio de Sá

Non-Presenting Co-Author

Arthur Costa

Universidade Estácio de Sá

\section{SessionIII}


Considering the geographical boundaries of the CRN1, this session covers challenges to access to justice, considered broadly as the access that citizens have to dispute resolution systems including but not limited to courts, but also to civil and administrative processes that might impact on protecting rights. Papers might include discussions on courts and litigation, as well as access to justice on its two dimensions: procedural access and also substantive justice.

Chair:Fernanda Duarte - UNESA e INCT/InEAC/PROPPI/UFF

Discussant:Rafael Mario Iorio Filho -Universidade Estácio de Sá e INCT-InEAC

\section{Majoritarian Precedent: The Case of Heightened Pleading Standards for Defendants}

In two famous cases, Twombly (2007) and Iqbal (2009), the U.S. Supreme Court raised the burden on plaintiffs trying to get their complaints heard in U.S. courts. In the decade since, lower courts have debated whether Twombly and Iqbal's heightened pleading standard for plaintiffs also applies to defendants and the affirmative defenses raised in their answers. Judges considering this question have split, repeatedly making a peculiar move along the way. Judges often identify one position or the other as the majority view, and then use the very fact of that view's popularity as a reason for their decision. This repeatedly occurs despite the fact that decisions of U.S. district courts are said to have no precedential value, and despite the fact that no court actually knows what the majority view really is. This paper does two things. First, it fills this knowledge gap by studying the 1,150 cases in which courts addressed the question in the decade after Twombly. It reveals what the majority view really is regarding heightened pleading standards for defendants, and how the majority view has changed over time. Second, the paper considers whether or when this knowledge should ever play a role in courts' decisions. The project aims to show how "majoritarian precedent" works in practice in the U.S. district courts--whether desirably or not--despite official doctrine which not only ignores it, but would hold it irrelevant.

Presenter- Brian Soucek- UC Davis School of Law

\section{A Difference in Deference: A New Approach to Understanding Judicial Deference to Bureaucratic Interpretations of Administrative Law}

This essay, which serves as one of the theoretical contributions of my dissertation project on the interbranch development of the administrative state, considers a new approach to considering judicial deference to administrative decision making. I argue that it is insufficient to simply use agency win rates as a proxy for judicial deference. Instead, I contend that in order to fully conceptualize the deferential relationship that exists between the judiciary and administrative agencies, we must look to the text of 
written opinions in cases involving an administrative agency for evidence that the courts are ruling in favor of an agency for a deferential reason rather than a political or precedential reason. Using a sample of cases where the Board of Immigration Appeals (BIA) is party to a lawsuit in the courts of appeals, I show that two step deferential intent (that a court is ruling in favor of an agency and that they are ruling in favor of an agency for a deferential reason) can be gleaned from the language of judicial opinion writers. I situate these insights into my larger dissertation project, which argues that in order to understand the development of the post-New Deal administrative state we must investigate courts and agencies as institutions that iteratively interact over time rather than as independent entities that develop independently.

Presenter

Rachel MacMaster- Syracuse University

\section{The Imperfect Relationship between Legal Procedures and Outcomes}

This paper considers the outcome-based approach to procedural justice in situations in which legal officials are required to apply legal standards to particular cases and in which the affected persons have a legal right to a specific outcome, such as social security benefits if they meet the relevant conditions or acquittal if they are not guilty of a crime with which they have been charged. Outcome-based theories maintain (i) that mistaken decisions that deny people the substantive outcomes to which they are legally entitled are unjust and (ii) that just procedures are procedures geared to avoiding this kind of substantive injustice. Thus legal officials should use procedures that protect our moral right to an accurate determination of our legal entitlements: procedural justice and substantive justice go hand in hand. Yet outcome-based theories also take the view that accuracy should not take priority over all other needs. The procedural protections necessary to avoid mistaken decisions are expensive, and there are other social goals, such as education and health, that also make legitimate claims on scarce resources. Can this package of claims be made coherent? This paper will address that question.

Presenter

Denise Meyerson - Macquarie University

\section{The Technological Access To Justice In The Network Society: Sharing (In)Justice}

The subject of the research is the analysis of a new way of access to justice, the technological one, constituted from the network society through massive online interaction. In working Law, the creation of virtual sharing platforms has enabled the electronic intermediation, a situation which is new in the international context. These technological advances have originated new conflicts, involving a whole universe of people. This scenery needs to be mapped so that new and efficient ways of prevention 
can be created and shared in order to avoid that any future injustices might happen in the future.

Presenter

Ana Carolina Reis Paes Leme - Universidade Federal de Minas Gerais

Non-PresentingCo-Author

Adriana Goulart de Sena Orsini- Universidade Federal de Minas Gerais

\section{Dispute Prevention Processes from a Civil Procedure Standpoint}

The 2016 reform of the Quebec Code of civil procedure provided a new obligation for the parties: to "consider private prevention and resolution processes before referring their dispute to the courts". Such an obligation consisted of a reversal in perspective in the civil procedure because it made private prevention and resolution processes, and not litigation, the default modes of resolution (Roberge, 2017). The Quebec Code of civil procedure states that the main private prevention and resolution processes include negotiation between the parties, mediation and arbitration. All these modes are traditionally used for dispute resolution, i.e. to resolve a dispute after it has emerged. What processes may be used for the purpose of dispute prevention? The legislator is silent in that regard. Dispute prevention has traditionally been associated with processes aiming at enhancing communications between stakeholders, such as facilitation or psychosociological intervention. However, what do dispute prevention processes mean from a civil procedure perspective? What role can lawyers play to assist their clients in preventing disputes from emerging? This paper will argue that dispute prevention processes from a civil procedure perspective are derived from two practices commonly used in the construction industry: rational risk allocation and partnering processes. It will describe such processes and explain how they could be applied beyond the remit of the construction industry.

Presenter

Véronique Fraser - Université de Sherbrooke

\section{Courts and Jugding in Asia and the Americas}

This session broadly covers judicial issues in Asia and the Americas. The focus will be on work related to courts, judges and judging in these areas. Examples might include discussions of the political role of judging; challenges faced by judges in relation to 
judicial independency, democracy, governments or social groups; judicial impartiality; judicial behavior; the psychological aspect of judicial decision making amongst others. Papers dealing with current empirical researches conducted in these regions are particularly encouraged.

\section{Session I}

Chair /Discussant: Fernanda Duarte - UNESA e INCT/InEAC/PROPPI/UFF

\section{Understanding the causes of brazilian "juristocracy": justices, judges and lawyers on the National Constituent Assembly of 1987}

The work returns to the causes of the judicialization of politics in Brazil, because it proposes to analyze the factors that allowed the expansion of the role of the STF in the Constitution of 1988. It is based on the contribution of Ran Hirschl (2005), which explains the worldwide movement that strengths judicial institutions, as product of the political dynamics among the internal power groups, in their confidence that "juristocracy" would be more favorable to them in the future (self-interest hegemonic preservation). In this universe, the author highlights the role of members of legal and judicial elites, as a relevant part in these processes, in their claim to increase their power and/or gain international reputation. The research supports the hypothesis that in Brazil it is possible to verify the suggestion of a juristocracyas a result of the political agreement that allowed the negotiated transition to democracy in the $1980 \mathrm{~s}$ - and justices, judges and lawyers were a key part of the process. For this purpose, empirical research is applied, from the perspective of historical analysis. Thus, texts and documents of the National Constituent Assembly of 1987, specially the Subcommittee of the Judiciary and the Public Prosecutor's Office, which promulgated the current constitution, serve as a basis for investigation.

Presenter - Flavia Lima - UNICAP

When $5 \times 4$ is not a winning majority: judicial decision-making on unconstitutional constitutional amendments

The main democratic critiques on the strong judicial review tend to disregard constitutional amendments as a mechanism to mitigate judicial supremacy. The main reason for this lies on the requirements of supermajority rules to amend a constitution. For political constitutionalism, supermajority rules do not offer equal treatment to those who will take part in the decision-making process, as this rule favors the maintenance of the status quo by making changes more difficult. Underlying this assertion is the belief that in democracy political equality depends on a decision-making process in which all opinions have the same value, mainly through simple majority. Moreover, the distrust in constitutional amendments as an instrument of dialogue is justified by the existence of 
judicial review on constitutional amendments. However, both constitutional courts and constitutional amendments are part of the majority democratic societies, therefore, we demonstrate how judicial review can be reconnected with the democratic potential of constitutional amendments. This is done through the use of supermajority rules in the constitutional courts deliberation, because, unlike what happens in parliaments, the maintenance of the status quo that it represents is advantageous for the presumption of constitutionality of constitutional amendments and does not mean violation to equal treatment since the democratic status of the courts does not come from the representativenss of their members.

Presenter

Jairo Lima - University of Sao Paulo

Presenting Co-Author

Rubens Beçak- University of Sao Paulo

\section{Judicial Dissent at the Crossroads: Judicial Voting in Macau's Courts}

There has been considerable debate on the merits of dissenting judgments versus a single judgment in courts. Laws that allow or prohibit dissents are indicative of the variety of views about it and reveal how lawmakers have balanced arguments in favor or against them. Studies from common law and civil law jurisdictions that recognize judges' right to dissent have identified the factors behind it. They influence the judges' choices and adjudication. The Macau SAR, China, allows public judicial dissent. Its legal system is almost entirely separate from that of mainland China, whereas its judicial system is fully separate, in spite of having connections to the mainland's political structure. The judiciary is formally independent, with strong differences between Macau's and the mainland's systems. The Portuguese legal and judicial systems, with their perspectives and structures, inspired those of Macau. Moreover, foreign judges may serve on the local courts. Portuguese have been serving at all levels of the judiciary. This paper discusses the dissent in the courts of Macau and investigate its determinants. It offers data from the courts' decisions and from interviews with legal actors. It suggests that existing explanations related to the local culture or to political pressure are currently non-predominant factors for the judges to vote in one voice or in dissent. Hence, group dynamics studies and theories are the best tools to understand the reality of judicial voting in Macau.

Presenter

Denis De Castro Halis- Faculty of Law / University of Macau 
Gender and judging: the enlargement of the judicial democratic legitimacy, considering the inclusion of underrepresented groups in the judicial function exercise

This work aims to discuss the centrality of the inclusion of sub-representative groups in spaces of power. Therefore, it seeks to discuss proposals which assume the importance of diversity in the judicial composition, especially, considering women's social perspective representation. The hypothesis points out that the institutions have always acted from a universalist conception and that the inclusion of the social perspectives of these groups in the decision-making processes could contribute for the democratic legitimacy expansion of the Judiciary, as well as improving the quality of judicial decisions. This work is divided into three parts. The first one will address the problems raised from the State's exclusion of women. The factors that operate for the underrepresentation itself (women are numerically smaller) will be analyzed and also the underrepresentation consequences for women who are outside the State. Subsequently, the data related to the analysis of 288 judicial decisions (given between 2008 and 2016) will be presented. These are related to the jurisprudential treatment given in Brazil by the Superior Court of Justice (STJ) to violence against women. Finally, we will demonstrate how the quality of the decisions vary (increasing or restricting the protection of women in situations of vulnerability) according to the Court's transformation - especially when there are more or less women present in the deliberation and decision moments.

Presenter

Cecilia Caballero Lois- Universidade Federal do Rio de Janeiro

\section{Session II}

Chair/:Discussant: Fernanda Duarte - UNESA e INCT/InEAC/PROPPI/UFF

\section{Jurisdiction in the State Court of Rio de Janeiro}

The jurisdiction in the State Court of Rio de Janeiro works in the following manner: A Brazilian citizen may open a legal process for the recovery of his rights if those rights have been disrespected or, as a result, damage has been caused. The Brazilian Constitution gives every citizen the right of access to the court system. It is there where, after hearing and evaluating each case, a judge comes to a decision. There are State trial courts in every city. They decide all cases involving civil or criminal laws. . If a plaintiff does not agree with the decision in his case, he can appeal to the State Supreme Court of Rio de Janeiro. There are 180 judges who preside in appellate courts to review the decisions of the lower courts. A complaint to a higher tribunal is made to correct an error of injustice made by the lower court. The 25 judges in Rio who have served the court the longest decide the cases which involve violations against the Constitution of the State of Rio de Janeiro. The Supreme Court in Brazilia decides the cases regarding 
the rights protected by the Brazilian Constitution. If the case involves those rights, a plaintiff may appeal to the Brazilian Supreme Court. If a plaintiff is unable to afford an attorney, according to the Brazilian Constitution, a public attorney must be provided by the state to defend the rights of any citizen in need.

Presenter

Ines da Trindade Chaves de Melo - UNESA

Participatory democracy as a mechanism for the emancipation of citizens. The figure of the Ombudsman in the solution of the service failures

The study of Administrative Law in Brazil has sought to strengthen Institutions as a way to improve democracy and allow states to provide improved public policy choices and service delivery. However, this choice has caused little gain in order to change passive behavior of the population, which shows little attention to the possibility of claiming their rights. Due to this fact, it is necessary to give importance to structures that allow more population participation by the possibility of the citizen to make a complaint about faults in the provision of services, in prestige to their fundamental rights.In this sense, it is important to forecast the figure of the Ombudsmen, who can initiate administrative procedures due to complaints of service failure and has decision-making power, although compliance with these decisions, when resisted, leads to the need to promote executive measures by the Judiciary. The advantage that we can point out in the existence of these ombudsmen is the fact that, because they are part of the Public Administration, has greater capacity to understand and dialogue with the other organs, and may even be someone with technical knowledge in the matter.In Brazil, there is no legal provision for the Ombudsman. In addition, it's easy to notice that, taking care of failure in the service that reaches the poor class, most of the lawsuits are filed by the extraordinary legitimates, which means that most of the problems do not even reach the Judiciary's judgment.

Presenter

Flavia Affonso - Fluminense Federal University; Advocacia-Geral da União

Social security litigation in Brazil and the challenges of access to justice: a comparative analysis of the administrative justice system in the common law countries

This article presents a study on social security litigation in Brazil and analyzes the challenges of the access to justice. There is a widespread perception that the Brazilian social security officers do not provide adequate protection to the citizens' rights. Spurred on by questionable decisions taken by non-independent civil servants, an increasing number of cases have been taken to the Federal Courts. As a result, citizens have their social security rights enforced by the Federal Courts, which have to deal with millions of cases each year. This paper argues that a lack of an administrative dispute resolution system in Brazil is a barrier to access to justice and causes heavy caseload in Federal Courts. This paper analyses the development of the administrative justice system in the 
common law countries and proposes that Brazil adopts a similar model in order to provide an independent and impartial social security adjudication system.

Presenter

Alexandre Arruda - Universidade Federal Fluminense 